\title{
Roles of environmental variables and land usage as drivers of dung beetle assemblage structure in mopane woodland
}

\author{
ADRIAN L.V. DAVIS, ${ }^{1}$ ANTHONY M. SWEMMER, ${ }^{2}$ CLARKE H. SCHOLTZ, ${ }^{1}$ CHRISTIAN \\ M. DESCHODT ${ }^{1}$ AND B. POWER TSHIKAE ${ }^{1}$ \\ ${ }^{1}$ Scarab Research Unit, Dept of Zoology \& Entomology, University of Pretoria, Private Bag X20, Hatfield, 0028 \\ South Africa and ${ }^{2}$ South African Environmental Observation Network, SAEON Ndlovu Node, Private Bag X1021, \\ Kruger National Park, 1390 South Africa \\ *Corresponding author: \\ Dr Adrian L.V. Davis \\ Scarab Research Unit, \\ Department of Zoology \& Entomology \\ University of Pretoria \\ Private Bag X20 \\ HATFIELD \\ 0028 South Africa \\ e-mail: adavis@zoology.up.ac.za
}

Tel. 0027124202539 (landline)

Tel. 0027781758441 (mobile)

Abstract Colophospermum mopane woodland covers large areas of dry lowland savanna in southeastern Africa. Dominant land usage is conservation (45\%) with the remainder mostly modified by farming. Dung beetle responses to environment (dung type, habitat, weather) and land usage (conservation, farming, mining) were examined at Phalaborwa $\left(23.9431^{\circ} \mathrm{S}\right.$ $31.1411^{\circ} \mathrm{E}$ ) in the Phalaborwa-Timbavati Mopaneveld, South Africa. Partitioning of gamma species richness and diversity showed lower alpha values in mine areas than in farm and conserved areas. However, between-land usage differences in species richness, alpha diversity, abundance and biomass, showed lower significance than those between dung type and different weather. At two sampling scales, three multivariate techniques variously separated assemblages 
according to land usage, dung type and weather. Analysis of 21 mean samples separated clusters according to dung type (Canonical Correspondence Analysis, CCA) or mine assemblages, conserved plus farm assemblages on pig plus elephant, or cattle dung (NMDS, Factor Analysis) with shared variance of $>80 \%$ and unique variance of $16-18 \%$ per cluster. In analysis of 188 samples (CCA), each overlapping dung type cluster was offset in ordinal space with congruent patterns of separation according to land usage and weather (drier days distant from moister days; conserved plus farm areas distant from early succession mine areas, which were distant from disturbed and later succession mine areas). Mining, dung types, and moist conditions were the strongest contributors to between-assemblage differences. Compared to conserved areas, dung beetle diversity is appreciably altered by mining but only slightly altered by intensive game farming or livestock ranching with subsistence agriculture.

Key words: Conservation $\cdot$ diversity $\cdot$ dung $\cdot$ environmental variables $\cdot$ habitat disturbance $\cdot$ land usage $\cdot$ mining $\cdot$ mopane woodland $\cdot$ weather

\section{Introduction}

Environmental disturbance is expanding due to pressures from burgeoning human populations (Dirzo \& Raven 2003). Thus, commercial exploitation of resources and the resulting habitat fragmentation has an ever-increasing impact on natural floral and faunal diversity (Fahrig 2003). In Africa, the effects of disturbance on vegetation, birds and large indigenous mammals are relatively well documented, with habitat destruction, alteration of habitat structure, and hunting responsible for widespread declines in species ranges and population densities (Happold 1995; Newmark 2008). Much less is known about impacts on other components of African

biodiversity, such as insects, which are, by far, the most diverse taxon outnumbering the totals of species for all other animals and plants combined (Stork 1988). Amongst the insects, dung beetles are particularly useful indicators of ecological disturbance (Halffter \& Favila 1993; Spector 2006). In forest and woodland ecoregions with a natural abundance of large mammals, dung beetle diversity and abundance are affected by both structural modification of vegetation and declining diversity of large mammal populations (Nichols et al. 2007; 2009). There is a limited literature on current trends (postdating 2000) in the biodiversity of dung beetles in disturbed areas of South Africa and southern Mozambique that focus on responses to 
environmental differences under different types of land usage (Botes et al. 2006; Simelane 2009; Jacobs et al. 2010; Davis et al. 2012) and on environmental changes induced by invasive vegetation (Coetzee et al. 2007) or post-mining vegetation restoration (Davis et al. 2002; 2003; Davis et al. 2013). However, such research has been conducted in relatively few vegetative ecotypes.

To investigate how dung beetles are affected by the most frequent types of disturbances in dry African woodlands, we compared species assemblages across a variety of land uses within the Zambezian and Mopane Woodland ecoregion (Olson et al. 2001), which is one of the major dry woodland types in southern Africa. Woodlands of this ecoregion are dominated by mopane trees (Colophospermum mopane) and cover large areas in the east (Zambezian and Mopane Woodlands - AT0725 - 473,191 $\mathrm{km}^{2}$ ) as well as in the west (Angolan Mopane Woodlands AT0702 - 133,384 $\mathrm{km}^{2}$ ) of southern Africa. Many large indigenous mammals are still found in the eastern ecoregion, where land usage is dominated by state and private conservation (45\%) (Estes \& Greyling 2012). However, disturbances typical of those throughout Africa also occur widely, including harvesting of live wood for firewood and construction (Makhado et al. 2009; 2012), stocking with domestic livestock (Musvoto et al. 2006), overstocking of indigenous herbivores for commercial hunting (Carruthers 2008), and large-scale habitat destruction caused by mining. Thus, typical modifications to dung beetle assemblages through land usage would result from structural changes to the habitat and changes in availability of food types.

Structural changes to habitats usually involve only vegetation cover but in the present study there are also changes in soil texture due to mining. Differences in dung beetle associations with soil type (Nealis 1971; Davis 1996) may be classified using soil grain-size profiles that reflect responses to relative hardness, drainage and moisture retention. These soil properties influence tunneling activity (Hanski \& Cambefort 1991) and survivorship of immatures (Fincher 1973). Dung beetle associations with the structural properties of vegetation are a response to microclimate factors resulting from shade, or lack of shade, particularly light intensity and temperature (Davis et al. 2013). Clearance of woody vegetation and loss of shade is one of the most frequent disturbance pressures experienced by dung beetles and is one of the main lines of investigation in the present study.

As different suites of chemical odours are released by different dung types (Dormont et al. 2010), dung beetle species may show either generalist or specialist associations with dung type 
(Martín-Piera \& Lobo 1996; Tshikae et al. 2008) according to the breadth or narrowness of their selective responses to these volatile attractants (Shibuya \& Inouchi 1982; Inouchi \& Shibuya 1986). Rarity or loss of any preferred dung type might impact on population size or exclude specialist dung beetles. It might also modify species richness due to loss of species associated with particular dung types (Tshikae et al. 2013a). As domestic livestock in farmland is usually dominated by pad or pellet-dropping ruminant herbivores, the rarity or loss of nitrogen-rich omnivore droppings and coarse-fibred droppings of monogastric herbivores is considered to be responsible for the rarity of specific groups of dung beetles in farmlands (Davis 1997). Thus, the other main line of investigation in the present study examines possible structural changes in dung beetle assemblages due to dung specialization, given the different mammal assemblages and suites of dung types available under different land usage and disturbance regimes.

Following substantial rainfall events, there is increased dung beetle activity (Davis 1995) if temperatures and light intensity are sufficiently high. If there is no further rainfall, soil conditions become dryer, temperatures increase, and dung beetle samples show both lower species richness and abundance. As results of the present study were collected under three different weather regimes, an assessment is also made of how results might have been influenced asymmetrically by different weather conditions during sampling.

In the present study, we compared dung beetle species assemblages from seven categories of land usage in mopane woodland. Sampling was conducted over three $24 \mathrm{~h}$ periods on two separate occasions (December 2011, January 2012) to determine the relative importance of habitat (soil, vegetation, disturbance), dung type and weather.

\section{Methods}

\section{Study area and study sites}

The study area was situated in the southern block of the Phalaborwa-Timbavati Mopaneveld (vegetation unit SVmp7 of Mucina \& Rutherford 2006) to the east and west of Phalaborwa $\left(23.9431^{\circ} \mathrm{S} 31.1411^{\circ} \mathrm{E}\right.$ ) (Fig. 1). According to Mucina \& Rutherford (2006), the area is characterized by a gently undulating plain on which soils are sandy on the ridges with greater clay fractions in the bottomlands. The undisturbed natural vegetation of the sandy ridges is 

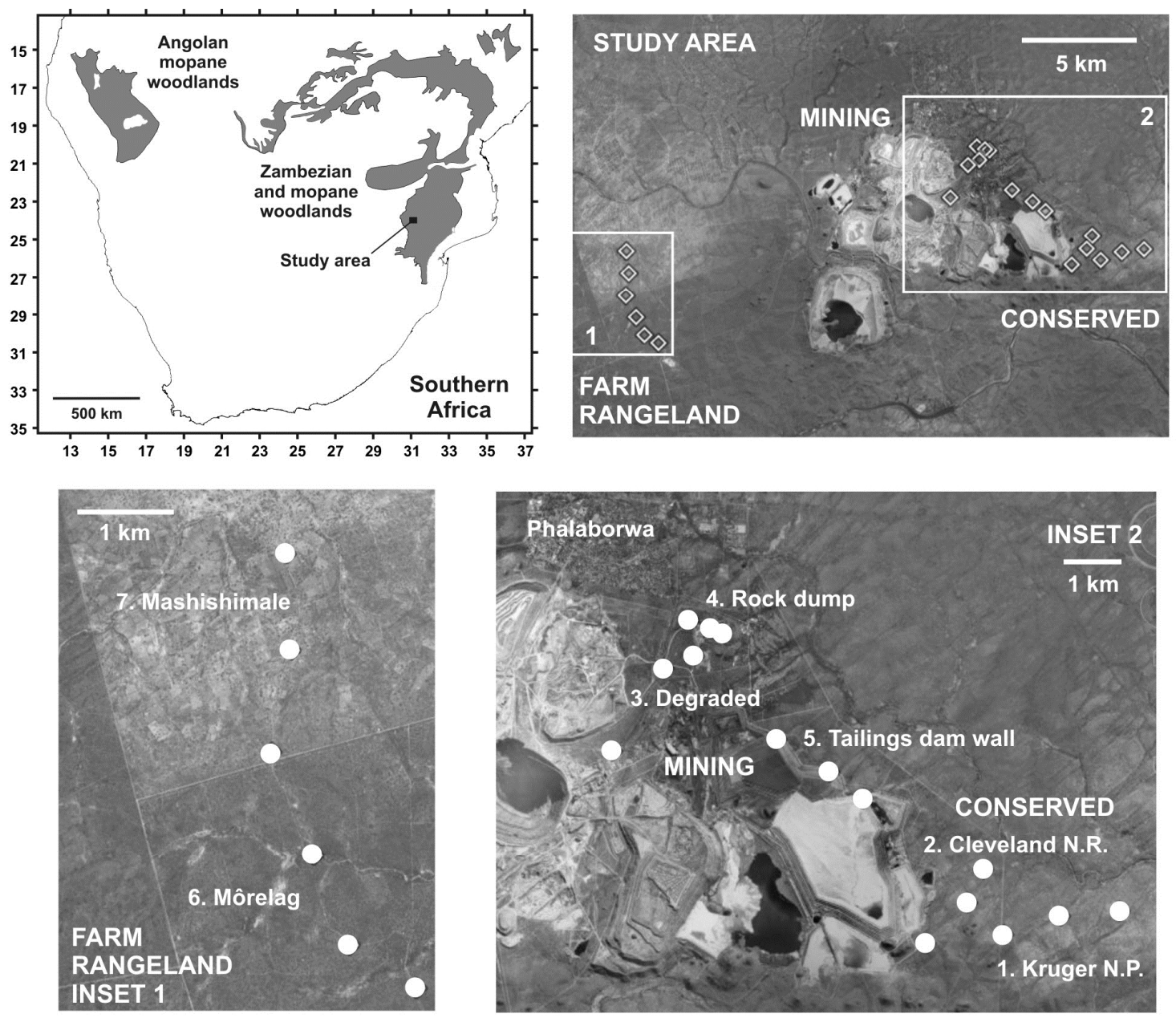

Fig. 1. Map showing mopane woodland ecoregions of southern Africa (Olson et al. 2001), location of the study area, and location of study sites plotted on Google Earth (2012).

characterized by open woodland dominated by Terminalia sericea Burch. Ex DC., Combretum apiculum Sond. and Colophospermum mopane (J. Kirk ex Benth.) J. Kirk ex J. Léonard. In the bottomlands, C. mopane dominates, with Acacia nigrescens Olivier replacing T. sericea and $C$. apiculum. However, these general patterns vary according to local factors as indicated by the descriptions of the study sites (Supplementary Table 1)

Three study sites were selected within each of seven study areas to represent a range of land usages and managements. These comprised conservation to the east of Phalaborwa, mining complexes in the vicinity of the town, and private or communal farming to the west (Fig. 1). The conserved areas in (1) the Kruger National Park and (2) Cleveland Nature Reserve were 
Table 1. Soil texture and woody vegetation cover in seven study areas under different land usage

\begin{tabular}{|c|c|c|c|c|}
\hline \multirow[t]{2}{*}{ Study Area } & \multicolumn{3}{|c|}{ Mean $\%$ soil texture \pm S.D. } & \multirow{2}{*}{$\frac{\% \text { woody cover }}{\text { Mean } \pm \text { S.D. }}$} \\
\hline & sand & silt & clay & \\
\hline \multicolumn{5}{|l|}{ Conservation areas } \\
\hline 1. Kruger N. P. & $79.9 \pm 5.1$ & $10.2 \pm 3.9$ & $9.9 \pm 4.5$ & $22.4 \pm 9.4$ \\
\hline 2. Cleveland N.R. & $74.0 \pm 8.0$ & $14.5 \pm 12.4$ & $11.5 \pm 5.1$ & $27.1 \pm 9.1$ \\
\hline \multicolumn{5}{|l|}{ Mining complex } \\
\hline 3. Degraded woodland & $79.7 \pm 10.9$ & $16.8 \pm 10.1$ & $3.5 \pm 2.8$ & $29.9 \pm 9.2$ \\
\hline 4. Rock dump & $90.8 \pm 1.1$ & $7.7 \pm 0.7$ & $1.5 \pm 0.3$ & $24.4 \pm 12.3$ \\
\hline 5. Tailings dam wall & $96.9 \pm 1.4$ & $3.1 \pm 1.4$ & 0.0 & $2.5 \pm 3.5$ \\
\hline \multicolumn{5}{|l|}{ Farm rangeland } \\
\hline 6. Game farm* & $79.4 \pm 6.7$ & $15.4 \pm 5.1$ & $5.2 \pm 1.9$ & $39.8 \pm 18.1$ \\
\hline 7. Communal range** & $79.7 \pm 5.1$ & $12.0 \pm 3.1$ & $8.2 \pm 5.0$ & $37.2 \pm 16.7$ \\
\hline
\end{tabular}

considered benchmark sites as soil, vegetation (Table 1) and indigenous mammal diversity were relatively undisturbed by human activity with similarities in mammal diversity supported by census data (Table 2) and camera traps (SAEON unpublished data). Areas in the mining complex compared extremes in land usage represented by (3) degraded natural vegetation and early (5 tailings dam wall) versus later extremes (4 - rock dump) of successional vegetation in areas of extreme modification by mining activities. Study areas in farm rangeland compared (6) a privately-owned game farm (Môrelag) where buffalo and various antelope were raised in relatively dense mopane woodland versus (7) the adjoining communal rangeland (Mashishimale) where high densities of domestic livestock were raised in open mopane / Acacia shrubland resulting from partial clearance for firewood and subsistence farming. Rutherford et al. (2012) described detailed differences in the plant species diversity and structure of the two farm rangeland study areas. 
Table 2. Density of large indigenous and domestic mammals (D) in conserved areas (Kruger N.P., Cleveland N.R.) and farm rangeland (Môrelag, Mashishimale) (nb. no published data for the industrial zone of the mining complex). In sequence from the top, grey and white panels separate coarse-dung-dropping monogastrics, pad-dropping ruminants, plus pellet dropping ruminants and other pellet-dropping herbivores (nb. no data for omnivores / carnivores)

\begin{tabular}{|c|c|c|c|c|}
\hline \multirow[t]{2}{*}{ Species } & \multicolumn{4}{|c|}{ Area $\left(\mathrm{km}^{2}\right)$ and mammal density $/ \mathrm{km}^{2}$ for year(s) } \\
\hline & $\begin{array}{c}\text { Kruger^}^{\wedge} \\
1304 \mathrm{~km}^{2} \\
1993,2007\end{array}$ & $\begin{array}{c}\text { Cleveland }{ }^{\wedge} \\
25.94 \mathrm{~km}^{2} \\
2007\end{array}$ & $\begin{array}{c}\text { Môrelag } \\
12.24 \mathrm{~km}^{2} \\
2012\end{array}$ & $\begin{array}{c}\text { Mashishim } \\
21.20 \mathrm{~km} \\
2010\end{array}$ \\
\hline Elephant & 0.62 & 1.66 & & \\
\hline White rhinoceros & 0.02 & 0.04 & & \\
\hline Burchell's zebra & 0.95 & 0.69 & & \\
\hline Donkey (D) & & & & 2.83 \\
\hline Buffalo & 0.87 & 6.90 & 8.99 & \\
\hline Cattle (D) & & & & 96.60 \\
\hline Giraffe & 0.26 & 0.66 & & \\
\hline Blue wildebeest & 0.22 & & 5.31 & \\
\hline Greater Kudu & 0.26 & 0.89 & 2.45 & \\
\hline Waterbuck & 0.14 & 1.47 & 1.63 & \\
\hline Impala & 5.32 & 13.22 & 5.72 & \\
\hline Sheep (D) & & & & 4.72 \\
\hline Goat (D) & & & & 27.78 \\
\hline
\end{tabular}

\footnotetext{
$\wedge^{\wedge}$ Less common pellet-dropping ruminant herbivores: Kruger N.P.:

Eland $0.02 / \mathrm{km}^{2}$, Sable $0.08 / \mathrm{km}^{2}$, Roan $0.001 / \mathrm{km}^{2}$; Cleveland N.R.:

Bushbuck $0.23 / \mathrm{km}^{2}$. Less common monogastric herbivores:

Cleveland N.R.: Hippopotamus $1.89 / \mathrm{km}^{2}$, Warthog $0.12 / \mathrm{km}^{2}$.

Origin of data:- Kruger N.P.: means of unpublished aerial census data

for 1987-1993 or 1985-2007 from mopaneveld on granite in the

Phalaborwa section of the Park; Cleveland N.R.: Palabora Mining

Company, unpublished "Biodiversity Action Plan", 2007; Môrelag:

K. Bekker (owner), 2012, pers. comm. to AMS; Mashishimale:

D. Makgalaboni (tribal authority representative), 2010, pers. comm.

to D. Thompson, J. Sibiya and M. Rutherford.
}

\section{Measurement of soil texture and vegetation cover density}

Soil texture and woody vegetation canopy cover were measured at each of the 21 study sites. Mean proportional compositions of sand, silt, and clay were measured from three samples for each study site. Woody vegetation cover was measured along three or four transects of 50 step points at each study site (25 step points at Môrelag, no data for degraded woodland site 2). Records were scored on the basis of presence (1) or absence (0) of canopy cover directly above each step point. These transects radiated from each trap location in the four cardinal directions 
with only three transects at endpoints on trap lines if they were orientated along cardinal directions.

\section{Trap emplacement and sampling protocol}

Where possible, the three study sites were separated by a measured road distance of $1 \mathrm{~km}$ within each of the seven study areas. At each study site, three 5 L pitfall traps (dimensions: top diameter $=22 \mathrm{~cm}$, depth $=16 \mathrm{~cm}$ ) were dug into the soil so that their rims were level with the soil surface. These three traps were separated from one another by a distance of $50 \mathrm{~m}$ as recommended by Larsen \& Forsyth (2005). On sampling occasions, the three traps at each site were baited with about $250 \mathrm{~mL}$ of cloth-wrapped pig (trap 1), cattle (trap 2), or elephant dung (trap 3), representing three major dung type divisions of omnivore, ruminant herbivore, and monogastric herbivore, each with quite different physical and chemical compositions (Dormont et al. 2010; Davis et al. 2012). These dung baits acted as natural representatives (elephant) or easily-obtained surrogates (pig, cattle) for dung types present in the study region and were supported at ground

level over each trap by two strong wires. Traps were baited on three $24 \mathrm{~h}$ occasions from $5^{\text {th }}$ to $6^{\text {th }}$ to $7^{\text {th }}$ December 2011 and $25^{\text {th }}$ to $26^{\text {th }}$ January 2012. Baiting or re-baiting was conducted at about $12 \mathrm{~h}$ intervals (early morning and late afternoon) to present fresh dung to both diurnally and nocturnally-active beetles.

\section{Analytical techniques}

Completeness of the species record for each dung type in each study area $(3 \times 7=21$ measurements) was tested using Cole rarefaction and two species estimator methods (Abundance-based Coverage Estimator and Bootstrap) contained in EstimateS version 8.2 (Colwell 2006). Estimates for each measurement were calculated from 50 randomizations of species data recorded at three study sites on three sampling occasions ( $3 \times 3=9$ samples).

Using a multiplicative method defined by Jost (2007), we partitioned gamma species richness and gamma exponential Shannon-Wiener diversity $\left(\mathrm{H}^{\mathrm{exp}}\right)$ into independent expressions for alpha and beta diversity (Supplementary Table 2). Separate analyses were conducted for each 
dung type across the seven study areas and each study area across the three dung types. Results were presented as a cross-tabulation (see Rös et al. 2012; Tshikae et al. 2013b).

Species richness, abundance, biomass, and exponential alpha diversity $\left(\mathrm{H}^{\exp }\right)$ per individual trap sample were tested for significant differences between seven land usage types, three dung types, and three sampling days under different weather conditions. GLM factorial ANOVA was used to test the relative influence of the three variables and for interactions. GLM one-way ANOVA was used to examine each of the three variables separately with Tukey's HSD test used to determine which elements of each variable were responsible for significant differences.

Patterns in dung beetle assemblage structure were defined and compared at two different sampling scales using three different ordination techniques. At a coarse scale, mean abundance data for 107 dung beetles species on three dung types in seven land usage types $(3 \times 7=21$ samples) were analyzed using both non-parametric (Multi-Dimensional Scaling - NMDS) and parametric ordination (Factor Analysis and Canonical Correspondence Analysis - CCA). For analysis at a fine scale of individual samples, statistical noise was reduced by deleting 40 species with a total abundance of $<10$ and analysis was conducted on abundance data for 67 species attracted to three dung types at three study sites in each of seven study areas on three sampling occasions ( $3 \times 3 \times 7 \times 3=188$ samples minus one missing). Analysis at fine scale was conducted using only CCA contained in the programme CANOCO version 4.55 (ter Braak \& Smilauer 2006). Use of multiple methods both generated different insights into beetle responses to environmental factors and permitted comparisons between the performances of the different techniques.

The coarse scale, 107 × 21 raw data matrix was $\log _{10}(n+1)$ transformed and a 21 × 21 correlation matrix was calculated. For analysis by NMDS, two dimensions were specified and similarities between assemblages were determined by fitting a minimum spanning tree to the data points of the ordination plot using the Kruskal algorithm contained in the computer package Arlequin version 3.1 (Escoffier et al. 2006). For Factor Analysis, principal components were used to extract factors. Three factors were the maximum that could be extracted. As oblique factors are often difficult to interpret, we conducted a Hierarchical Analysis of Oblique Factors (see Wherry 1984). Clusters of study sites were defined at the default factor score level of 0.7 and subjected to varimax-normalized rotation of factors through clusters, which maximizes 
between-cluster variance. Rotated, oblique factor loadings were then subjected to a second Factor Analysis to generate extended orthogonal factors. Correlations $\left(r^{2}\right)$ between extended orthogonal and oblique factor loadings were used to determine the proportion of unique character contributed by primary $(\mathrm{P})$ extended factors within each cluster, and the proportion in common with other clusters, due to shared secondary $(\mathrm{S})$ factors.

The coarse $(107 \times 21)$ and fine scale $(67 \times 188)$ raw data matrices were also $\log _{10}(n+1)$ transformed before direct gradient analysis by CCA, which constrains patterns generated from species data according to patterns in the environmental data. The study focused on inter-sample differences at the CANOCO default settings of "Do not use forward selection and biplot scaling". Monte Carlo statistical tests were conducted in CCA using 499 permutations (restricted model) in order to determine if there were significant associations between dung beetle species distributions and environmental variables. Vector lines representing the average influences of various environmental factors were fitted to ordination plots representing distances between assemblages. At coarse scale, the matrix used to fit vector lines comprised a cross-tabulation of 21 samples (assemblages) by six dummy (categorical) environmental variables (coded using " 1 " or "0") comprising dung type (pig, cattle, elephant) and land usage (conservation, mining, farm rangeland). At fine scale, the matrix used to fit vector lines comprised a cross-tabulation of 188 samples by 13 environmental variables in which dummy variables were used to fit lines for dung type, land usage and sampling day (days 1, 2, 3) whereas percentage values were used to fit lines for soil texture (sand, clay) and vegetation cover (open grassy versus shaded woody cover). As lengths of the vector lines indicate the relative strength of each environmental influence, these lines were measured and expressed as a proportion of the longest vector within each ordination plot.

\section{Results}

\section{Diversity in habitat, large mammals and weather on sampling days}

There were differences between study areas along the three major resource dimensions of space, food and time (Tables 1, 2, Supplementary Table 1, Fig. 2). Spatial variation included both differences in soil texture and woody vegetation cover according to land usage (Table 1). 


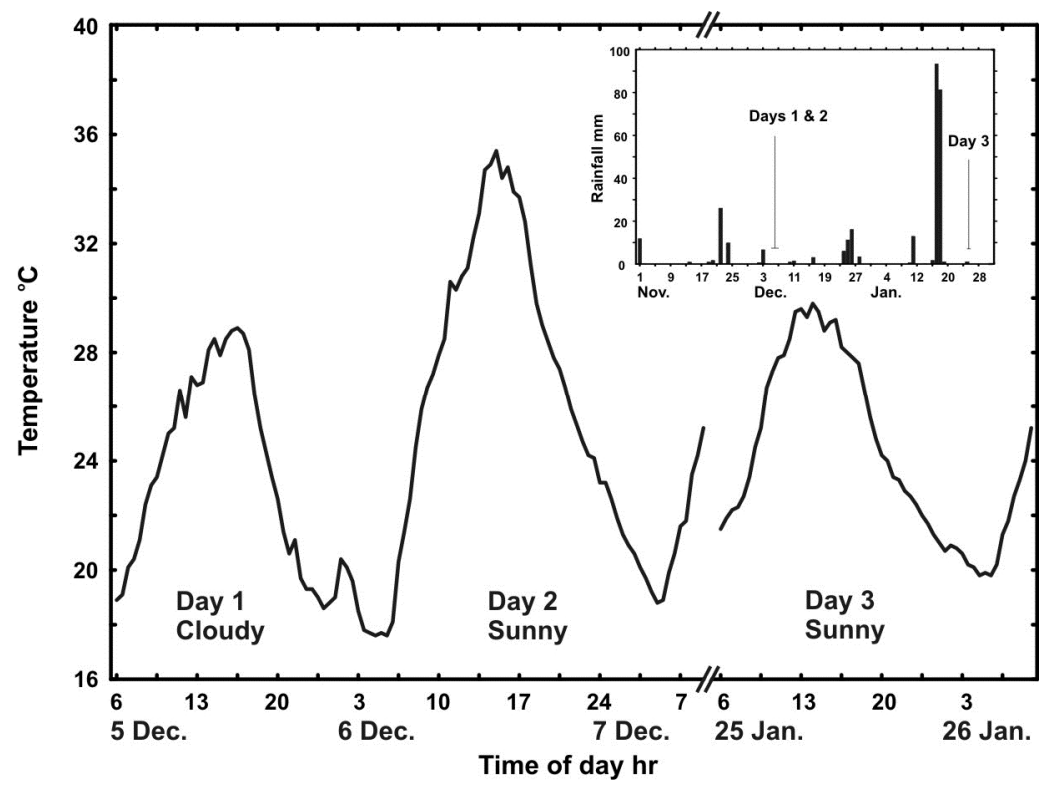

Fig. 2. Temperatures on sampling occasions (Days 1-3) and rainfall history between November 2011 and January 2012 at the SAEON Ndlovu node offices $\left(23.9450^{\circ} \mathrm{S} 31.1654^{\circ} \mathrm{E}\right)$, Phalaborwa, which lay within 2.3 to $9.4 \mathrm{~km}$ from the mine and Kruger N.P. study sites and within 18.1 to $19.1 \mathrm{~km}$ from farm study sites.

Undisturbed granite-derived soils in conserved $(1,2)$, farmed $(6,7)$ and degraded mine (3) study areas were relatively sandy with much smaller silt fractions. However, on the rock dump (4) and the tailings dam wall (5), soils created by mining activity comprised even greater sand fractions. Shade offered by woody vegetation cover was severely limited in the early succession vegetation of the tailings dam wall (5) (Table 1). Although there was greater woody vegetation cover in other study areas of the mining complex $(3,4)$ and in conserved areas $(1,2)$, it was rather more open than the somewhat denser cover in farm rangeland $(6,7)$ where there was a long history of heavy grazing but no elephants (Table 2).

Diversity and density of large-bodied mammals varied between study areas (Table 2). As parts of the fence between the Kruger N.P. (1) and Cleveland N.R. (2) had ceased to be an effective barrier to large mammals prior to the study, both conserved areas supported a diverse assemblage of large-bodied indigenous mammals dropping a range of dung types (Table 2). This included omnivores and carnivores although no census data were available for these species. There were also no census data available for the industrial zone of the mining complex, which lies at the eastern edge of the mining operation (Fig. 1). However, it also supported a diverse 
assemblage of indigenous mammals as there is no fence preventing their movement from Cleveland N.R. In the farm rangeland, large indigenous mammals were absent from Mashishimale and reduced in diversity on Môrelag where there was an absence of large monogastric herbivores (Table 2) although omnivore baboons were observed. Large domestic mammals in Mashishimale included pad and pellet-dropping ruminant herbivores as well as monogastric herbivores.

Weather conditions varied between the three sampling occasions. Day $1\left(^{\text {th }}\right.$ to $6^{\text {th }}$ December) was mild to warm (Fig. 2) but cloudy with late afternoon sun. Although there had been light rain two days previously, it was some 11-13 days since the previous substantial rainfall. Day 2 ( $6^{\text {th }}$ to $7^{\text {th }}$ December) was hot and sunny whereas Day 3 ( $25^{\text {th }}$ to $26^{\text {th }}$ January) was warm and sunny some 7-8 days following exceptionally heavy rainfall.

\section{Dung beetle responses to environmental variables}

Species accumulation was comparable for each dung type in each study area (Supplementary Fig. 1). The mean rate of species accumulation on elephant dung was a little lower than that on cattle dung, which was a little lower than that on pig dung. The proportion of species observed against numbers predicted ranged between 66.9-96.8\% for the Abundance-based Coverage Estimator (Supplementary Figure 1) but was a more consistent 85.1-95.8\% using the Bootstrap method. It is considered that these results indicate a fairly complete record of the species that were present.

Partitioning of gamma species richness and exponential gamma diversity $\left(\mathrm{H}^{\exp }\right)$ showed both similarities and differences in trends between study areas and dung types (Tables 3A, 3B). For the most part, species richness on all dung types was a little lower in the industrial zone of the mining complex than in conserved and farm rangeland areas, a pattern that was accentuated by the alpha component of species richness (Table 3A). There was an opposing trend of increased beta diversity in the more disturbed mine complex indicating greater species turnover between dung types than in conserved and farm rangeland areas. Structural diversity $\left(\mathrm{H}^{\exp }\right)$ (Table 3B) was also relatively low in the mine complex but differed to species richness in also showing low diversity in Cleveland N.R. Opposite to the trend shown for species richness, there was a trend to slightly lower beta diversity in the mine complex indicating lower structural 
Table 3. Multiplicative partitioning of species richness and exponential Shannon-Wiener diversity $\left(\mathrm{H}^{\mathrm{exp}}\right)$ for dung beetle assemblages recorded on three dung types in seven study areas under different land usage with values for beta diversity also cited on a $0-1$ scale

A. Species richness $\left(\text { Gamma }{ }^{0} \mathrm{D}_{\gamma} \text {, Beta }{ }^{0} \mathrm{D}_{\beta} \text { and } \beta(0-1) \text {, Alpha }{ }^{0} \mathrm{D}_{\alpha}\right)^{\wedge}$

\begin{tabular}{|c|c|c|c|c|c|c|c|c|c|c|c|}
\hline \multirow[b]{2}{*}{ Dung type } & \multicolumn{2}{|c|}{ Conserved* } & \multicolumn{3}{|c|}{ Mine complex* } & \multicolumn{3}{|c|}{ Farm rangeland* } & \multirow[b]{2}{*}{${ }^{0} \mathrm{D}_{\alpha \text { (site) }}$} & \multirow[b]{2}{*}{${ }^{0} \mathrm{D}_{\beta}$ (site) } & \multirow[b]{2}{*}{$\beta_{(0-1)}$} \\
\hline & $\begin{array}{c}\mathrm{KNP} \\
{ }^{0} \mathrm{D}\end{array}$ & $\begin{array}{c}\text { Cleve. } \\
{ }^{0} \mathrm{D}\end{array}$ & $\begin{array}{c}\text { Degr. } \\
{ }^{0} \mathrm{D}\end{array}$ & $\begin{array}{l}\text { Rock } \\
{ }^{0} \mathrm{D}\end{array}$ & $\begin{array}{c}\text { Tail. } \\
{ }^{0} \mathrm{D}\end{array}$ & $\begin{array}{l}\text { Game } \\
{ }^{0} \mathrm{D}\end{array}$ & $\begin{array}{l}\text { Com. } \\
{ }^{0} \mathrm{D}\end{array}$ & ${ }^{0} \mathrm{D}_{\gamma(\text { site })}$ & & & \\
\hline Pig & 61 & 56 & 50 & 54 & 39 & 55 & 61 & 91 & $\overline{53.71}$ & 1.99 & 0.28 \\
\hline Cattle & 50 & 53 & 40 & 41 & 44 & 46 & 51 & 76 & 46.43 & 2.31 & 0.33 \\
\hline Elephant & 48 & 50 & 43 & 48 & 38 & 54 & 52 & 81 & 47.57 & 2.25 & 0.32 \\
\hline${ }^{0} \mathrm{D}_{\gamma \text { (dung) }}$ & 73 & 71 & 67 & 69 & 57 & 64 & 72 & & & & \\
\hline${ }^{0} \mathrm{D}_{\alpha \text { (dung) }}$ & 61.33 & 53.00 & 44.33 & 47.67 & 40.33 & 51.67 & 54.67 & & & & \\
\hline${ }^{0} \mathrm{D}_{\beta \text { (dung) }}$ & 1.75 & 2.02 & 2.41 & 2.25 & 2.65 & 2.07 & 1.96 & & & & \\
\hline$\beta_{(0-1)}$ & 0.58 & 0.67 & 0.80 & 0.75 & 0.88 & 0.69 & 0.65 & & & & \\
\hline
\end{tabular}

B. Exponential Shannon-Wiener diversity $\left(\mathrm{H}^{\mathrm{exp}}\right)\left(\operatorname{Gamma}{ }^{1} \mathrm{D}_{\gamma} \text {, Beta }{ }^{1} \mathrm{D}_{\beta} \text { and } \beta_{(0-1)} \text {, Alpha }{ }^{1} \mathrm{D}_{\alpha}\right)^{\wedge}$

\begin{tabular}{|c|c|c|c|c|c|c|c|c|c|c|c|}
\hline \multirow[b]{2}{*}{ Dung type } & \multicolumn{2}{|c|}{ Conserved* } & \multicolumn{3}{|c|}{ Mine complex* } & \multicolumn{3}{|c|}{ Farm rangeland* } & \multirow[b]{2}{*}{${ }^{0} \mathrm{D}_{\alpha \text { (site) }}$} & \multirow[b]{2}{*}{${ }^{0} \mathrm{D}_{\beta \text { (site) }}$} & \multirow[b]{2}{*}{$\beta_{(0-1)}$} \\
\hline & $\begin{array}{c}\mathrm{KNP} \\
{ }^{0} \mathrm{D}\end{array}$ & $\begin{array}{c}\text { Cleve. } \\
{ }^{0} \mathrm{D}\end{array}$ & $\begin{array}{l}\text { Degr. } \\
{ }^{0} \mathrm{D}\end{array}$ & $\begin{array}{l}\text { Rock } \\
{ }^{0} \mathrm{D}\end{array}$ & $\begin{array}{c}\text { Tail. } \\
{ }^{0} \mathrm{D}\end{array}$ & $\begin{array}{c}\text { Game } \\
{ }^{0} \mathrm{D}\end{array}$ & $\stackrel{\text { Com. }}{{ }^{0} \mathrm{D}}$ & ${ }^{0} \mathrm{D}_{\gamma \text { (site) }}$ & & & \\
\hline Pig & 14.03 & 7.13 & 3.05 & 4.92 & 8.60 & 14.87 & 16.66 & 10.04 & 7.69 & 1.31 & 0.19 \\
\hline Cattle & 13.78 & 10.86 & 6.68 & 9.34 & 12.23 & 16.58 & 14.94 & 15.30 & 11.55 & 1.33 & 0.19 \\
\hline Elephant & 8.88 & 4.11 & 4.16 & 6.66 & 7.10 & 19.14 & 10.62 & 10.24 & 7.44 & 1.38 & 0.20 \\
\hline${ }^{1} D_{\gamma \text { (dung) }}$ & 15.08 & 7.70 & 4.04 & 6.53 & 10.31 & 18.95 & 17.63 & & & & \\
\hline${ }^{1} \mathrm{D}_{\alpha \text { (dung) }}$ & 12.62 & 7.21 & 3.79 & 5.91 & 8.97 & 16.11 & 14.95 & & & & \\
\hline${ }^{1} \mathrm{D}_{\beta \text { (dung) }}$ & 1.20 & 1.07 & 1.07 & 1.11 & 1.15 & 1.18 & 1.18 & & & & \\
\hline$\beta_{(0-1)}$ & 0.40 & 0.36 & 0.36 & 0.37 & 0.38 & 0.39 & 0.39 & & & & \\
\hline
\end{tabular}

*Land usage:- Conserved - 1. KNP: Kruger National Park, 2. Cleve.: Cleveland Nature Reserve; Mine complex - 3. Degr.: Degraded woodland, 4. Rock: Rock dump, 5. Tail.: Tailings dam wall; Farm rangeland - 6. Game: Game farm (Môrelag), 7. Com.: Communal rangeland (Mashishimale). ${ }^{\wedge}$ Each total species or diversity value derived from data for three traps per study area on three sampling occasions, 3 × $3=9$.

turnover between dung types than in conserved and farm rangeland areas. Compared to a theoretical minimum beta diversity of 1 (100\% similarity between assemblages) and theoretical maxima of 3 for dung type ( $\beta$ dung) and 7 for study areas ( $\beta$ site) $(0 \%$ similarity between assemblages), which are equivalent to the numbers of distinct communities, multiplicative values 
for beta diversity indicated about two communities in terms of species richness (Table 3A) but only about one in terms of structural diversity (Table 3B). Re-scaling beta diversity values from 0 to 1 illustrates that turnover in both species richness and structural diversity was greater between dung types than between study areas (Table 3). Gamma and alpha species richness were higher on pig dung than on elephant and cattle dung whereas structural diversity was higher on cattle dung than either pig or elephant dung.

Table 4. Values for $F$ from GLM factorial ANOVA examining the effect of weather conditions (sample day), dung types, land usage, and interactions on species richness (number of species), diversity (exponential ShannonWiener diversity $-\mathrm{H}^{\text {exp }}$ ), abundance, and biomass (gram dry weight) of dung beetles per individual trap sample ( $\mathrm{n}=188$, one sample missing)

\begin{tabular}{lccccccc}
\hline $\begin{array}{l}\text { Dung beetle } \\
\text { parameters }\end{array}$ & $\begin{array}{c}\text { Sample } \\
\text { day^}\end{array}$ & $\begin{array}{c}\text { Dung } \\
\text { type }\end{array}$ & $\begin{array}{c}\text { Land } \\
\text { usage }\end{array}$ & $\begin{array}{c}\text { Day* } \\
\text { dung }\end{array}$ & $\begin{array}{c}\text { Day* } \\
\text { usage }\end{array}$ & $\begin{array}{c}\text { Dung* } \\
\text { usage }\end{array}$ & $\begin{array}{c}\text { Day*dung* } \\
\text { usage }\end{array}$ \\
& $F_{(2,125)}$ & $F_{(2,125)}$ & $F_{(6,125)}$ & $F_{(4,125)}$ & $F_{(12,125)}$ & $F_{(12,125)}$ & $F_{(24,125)}$ \\
\hline Species richness & $70.282^{* * *}$ & $64.154^{* * *}$ & $8.939^{* * *}$ & $9.680^{* * *}$ & $3.554^{* * *}$ & 1.096 & 0.619 \\
Diversity (H $\left.\mathrm{H}^{\text {exp }}\right)$ & $73.085^{* * *}$ & $15.416^{* * *}$ & $12.183^{* * *}$ & $6.749^{* * *}$ & 0.961 & $1.834^{*}$ & 0.789 \\
Abundance & 0.328 & $62.207^{* * *}$ & $7.620^{* * *}$ & $7.730^{* * *}$ & $4.420^{* * *}$ & $1.906^{*}$ & 1.500 \\
Biomass (g) & $45.953^{* * *}$ & $65.166^{* * *}$ & $7.429^{* * *}$ & $2.821^{*}$ & $3.653^{* * *}$ & 1.762 & 1.252
\end{tabular}

\footnotetext{
${ }^{\wedge}$ Three dung types at each of three study sites in seven study areas under different land usage on three sampling days with different weather. Probabilities: $* P<0.05, * * * P<0.001$
}

The four variables of species richness, exponential alpha diversity $\left(\mathrm{H}^{\mathrm{exp}}\right)$, abundance and biomass (dry mass g) mostly showed significant differences according to study area (land usage), dung type, and sampling day (Table 4). The relative influences of dung type and weather on sampling days were much stronger than those of land usage. $F$ values for interactions between variables were mostly much lower than those for single variables and sometimes not statistically significant. There were significant differences in mean values per sample in all of 12 comparisons except abundance per sampling day (Fig. 3). While land use patterns were variable, mean species richness and mean alpha diversity were generally lower in the mining complex. Values were particularly low for the tailings dam wall and less so for the rock dump. The latter also showed high values for abundance and biomass comparable to those found for the farm 

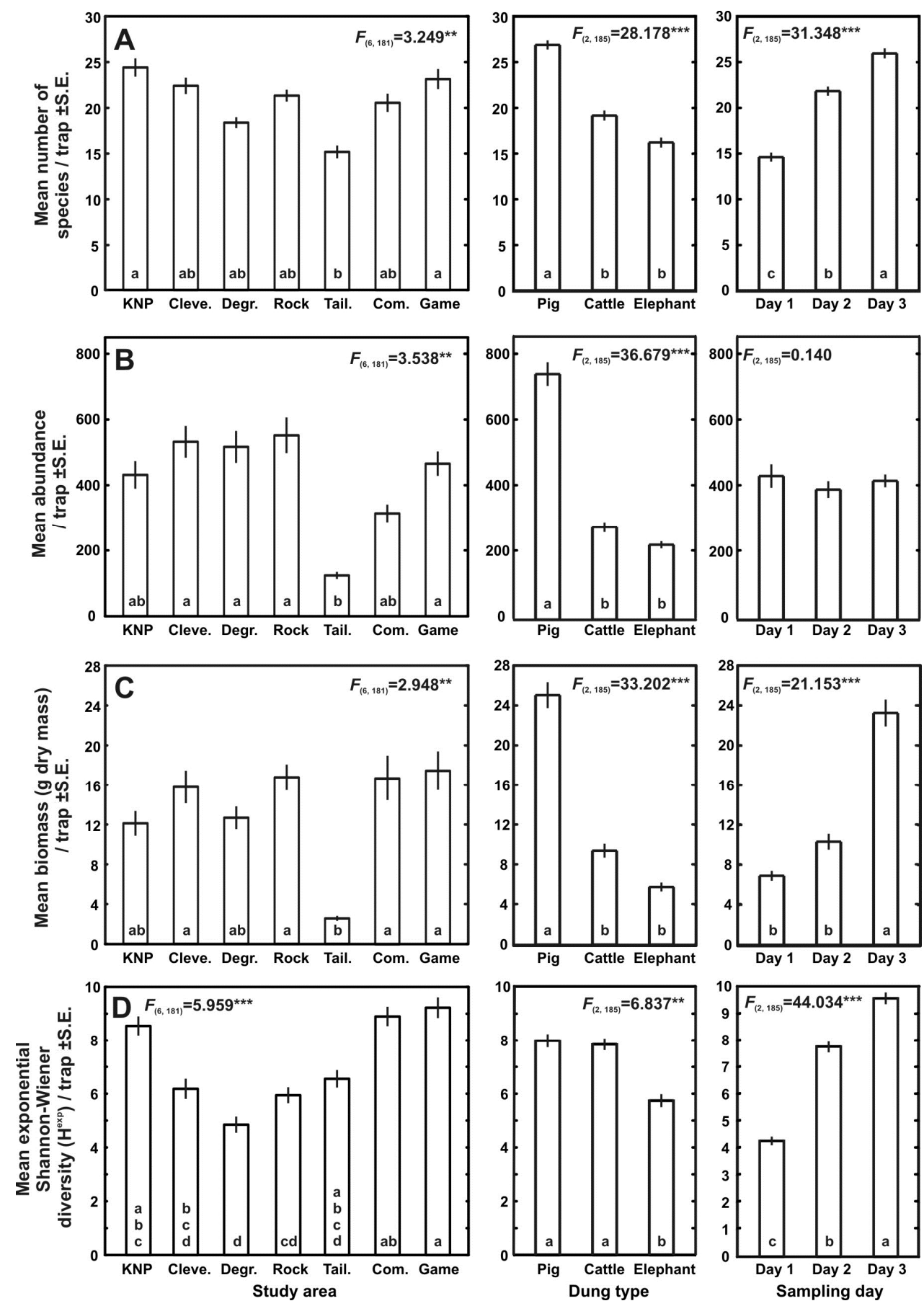

Fig. 3. Mean values per sample and results from GLM one-way ANOVA for dung beetles recorded on three sampling days with different weather conditions, three dung types, and seven study areas under different land usage $\left({ }^{* *} P<0.01,{ }^{* * *} P<0.001\right)$. A. Species richness. B. Abundance. C. Biomass (gram dry weight). D. Exponential alpha diversity. Land usage: Conserved - KNP: Kruger National Park, Cleve.: Cleveland Nature Reserve; Mining complex - Degr.: Degraded woodland, Rock: Rock dump, Tail.: Tailings dam wall; Farm rangeland - Game: Game farm (Môrelag), Com.: Communal rangeland (Mashishimale). In each separate unit of the figure, bars with different letters differed significantly $(P<0.05$ - Tukey's HSD). 
rangeland areas and the Kruger N.P. Exceptionally low values for the highly disturbed tailings dam wall were responsible for most of the significant variation in species richness, abundance and biomass. The large amount of variance accounted for by dung type was a result of the significantly higher values on pig dung compared to cattle and elephant dung for all four variables except diversity $\left(\mathrm{H}^{\prime}\right)$, for which values were similar on pig and cattle dung. Similarly,
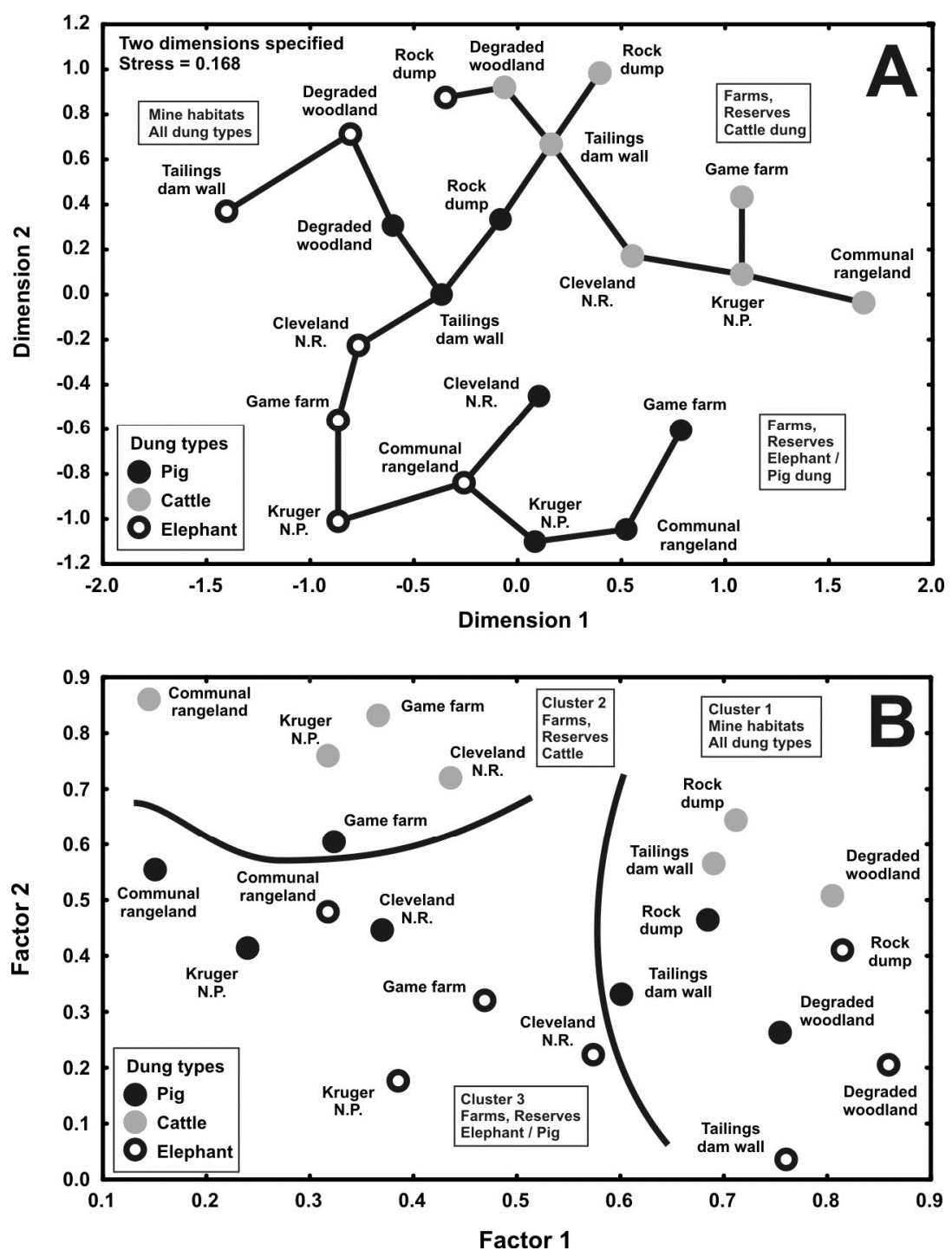

Fig. 4. Ordination plots showing statistical distance between the structure of 21 dung beetle assemblages recorded on three dung types in seven study areas under different land usage. A. NMDS with a minimum spanning tree fitted to the data points. B. Factor analysis with hierarchical analysis of oblique factors. 
high levels of significance were reflected by the hierarchy of significantly higher values on day 3 to day 2 to day 1 for all four variables except abundance, which was similar on all occasions. Although abundance did not differ significantly between the warm moist conditions on day 3 compared to the hot dry conditions on day 2 and the mild to warm but cloudy conditions on day 1 (Fig. 2), biomass was far greater on day 3, indicating that large-bodied species were relatively more active than on the other two days.

At a coarse scale of 107 species by 21 variables for land usage and dung type association, both non-parametric (NMDS) and parametric ordination (Factor Analysis) yielded similar results (Figs 4A, 4B). These were represented either by neighbouring NMDS data points along branches on a minimum spanning tree or by clusters of data points defined by hierarchical analysis of oblique factors. Similar groupings of study areas comprised (1) all dung types in the industrial zone of the mining complex, (2) pig plus elephant dung in conserved plus farm rangeland areas, or (3) cattle dung in conserved plus farm rangeland areas (includes one pig dung data point in the Factor analysis). The Factor Analysis accounted for $>86 \%$ of total variance (Table 5) and supported significant differences between clusters represented by combinations of land usage and dung type (Fig. 3) although $82-84 \%$ of the variance was shared and only $16-18 \%$ was unique to each cluster (Table 5).

Table 5. Eigenvalues, percentage variance, and correlations between oblique and extended orthogonal factors from Factor Analysis of the structure of 21 dung beetle assemblages on three dung types in seven study areas under different land usage (see Fig. 4B)

\begin{tabular}{lrrrrrrr}
\hline $\begin{array}{l}\text { Oblique } \\
\text { factors } \\
\text { (Clusters) }\end{array}$ & $\begin{array}{c}\text { Eigen } \\
\text { value }\end{array}$ & $\begin{array}{c}\% \\
\text { variance }\end{array}$ & $\begin{array}{c}\text { Cumulative } \\
\% \text { variance }\end{array}$ & \multicolumn{3}{c}{$\begin{array}{c}\text { Extended and oblique factor correlations, } r\left(r^{2}\right) \\
\text { Extended orthogonal factors* }\end{array}$} \\
\hline Factor 1 & 15.30 & 72.9 & 72.9 & $-0.91(0.82)$ & $0.42(0.18)$ & 0.0 & Primary 3 \\
Factor 2 & 1.51 & 7.2 & 80.1 & $-0.91(0.82)$ & 0.0 & $0.42(0.18)$ & 0.0 \\
Factor 3 & 1.34 & 6.4 & 86.5 & $-0.92(0.84)$ & 0.0 & 0.0 & $0.40(0.16)$
\end{tabular}

*Secondary extended factor: shared variance; Primary extended factors: unique variance, both derived from hierarchical analysis of oblique factors

At coarse scale, the biplot derived from Canonical Correspondence Analysis (CCA) showed clear separation between assemblages according to dung type (Fig. 5) with the first four axes accounting for $76.4 \%$ of the variance in assemblage structure (Table 6A). The vector lines 
Table 6. Statistics generated by direct gradient, Canonical Correspondence Analysis (CCA) of dung beetle assemblage structure. A. Coarse scale analysis of 21 , meaned samples on different dung types in different land usage categories. B. Fine scale analysis of 188 samples on different dung types under different weather conditions in different land usage categories (see Figs 5, 6)

\begin{tabular}{lcccc}
\hline Ordination & \multirow{2}{*}{$\begin{array}{l}\text { Eigen } \\
\text { axes }\end{array}$} & \multicolumn{2}{c}{ Cumulative \% variance } & \multicolumn{2}{c}{$\begin{array}{c}\text { Correlati } \\
\text { values }\end{array}$} & & \\
\cline { 3 - 4 } & & Spp. / Env. & \\
\cline { 3 - 4 } & & & & \\
\hline A. Coarse & & & & \\
Axis 1 & 0.129 & 32.2 & 42.1 & 0.99 \\
Axis 2 & 0.133 & 60.5 & 79.2 & 1.00 \\
Axis 3 & 0.036 & 69.6 & 99.1 & 0.91 \\
Axis 4 & 0.027 & 76.4 & 100.0 & 0.97 \\
B. Fine & & & & \\
Axis 1 & 0.166 & 8.7 & 27.7 & 0.90 \\
Axis 2 & 0.136 & 15.8 & 50.3 & 0.92 \\
Axis 3 & 0.093 & 20.7 & 65.9 & 0.86 \\
Axis 4 & 0.068 & 24.3 & 77.3 & 0.79 \\
& & & & \\
\hline
\end{tabular}

Spp. / Env. = Species / Environment relationship

showed that variance for pig dung assemblages in the mining area, cattle dung assemblages in the conserved areas and elephant dung in the farm rangeland had the greatest influence with the other six land usage / dung type vectors having lower and intermediate degrees of influence. The overlap between the influences of land usage and dung type are, perhaps, responsible for the lack of significant associations between species distributions and environmental variables for canonical axes in CCA (Monte Carlo tests on all canonical axes: value $=0.305, F=0.809, P=0.54$; on Axis 1: value $=0.129, F=0.475, P=0.66$ ).

Because of greater variation at the fine scale of 67 abundant species by 188 samples for spatial, trophic and temporal variation, the first four CCA axes accounted for only $24.3 \%$ of the variance in assemblage structure (Table 6B). However, there were significant associations between species distribution and environmental variables (Monte Carlo tests on all canonical axes: value $=0.600, F=9.046, P=0.002$; on Axis 1 : value $=0.166, F=16.918, P=0.002$ ). For each dung type, there were clear repeated patterns in distribution of data points for other environmental variables. However, these congruent patterns for pig, elephant and cattle dung were clearly offset from one another with a wide angular separation of the vector lines for dung type that passed through the centre of each group of data points (Fig. 6). Within each repeated 


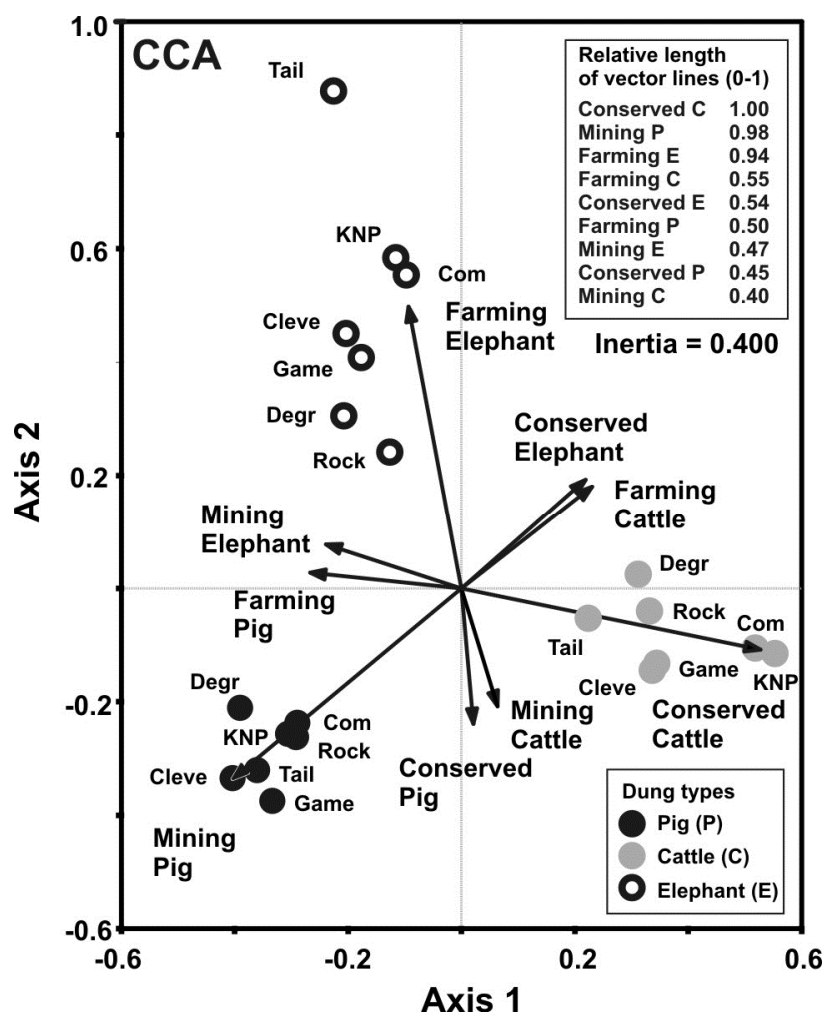

Fig. 5. Ordination plot derived from direct gradient, Canonical Correspondence Analysis (CCA) showing statistical distances between 21 dung beetle samples coded according to dung type. Vector lines represent the average trajectory of combined influences from dung type and land usage (Conserved includes: Kruger National Park (KNP) and Cleveland Nature Reserve (Cleve); Mining includes: Degraded woodland (Degr), Rock dump (Rock), and Tailings dam wall (Tail); Farming includes: Game farm (Môrelag) (Game) and Communal rangeland (Mashishimale) (Com)). Lengths of vector lines represent the relative strength of combined spatial and trophic influences on patterns of assemblage structure.

pattern for the three dung types, similar separation between groups of data points were shown for sample days (days 1 and 2 well separated from day 3) and land usage (combined groups of conservation and farm rangeland samples well-separated from those for the tailings dam wall which are well-separated from the other mine complex samples) (Fig. 5A).

At fine scale, relative lengths of the vector lines indicate that mining, dung type, and warm conditions following heavy rainfall (day 3) were all more influential than other environmental factors (conservation, farm rangeland, drier weather on days 1 and 2, soil texture, vegetation cover) (Fig. 6). Vectors for mining, sand, and open vegetation, showed similar trajectories reflecting the higher proportions of sand on the rock dump and, also, the tailings dam wall where 


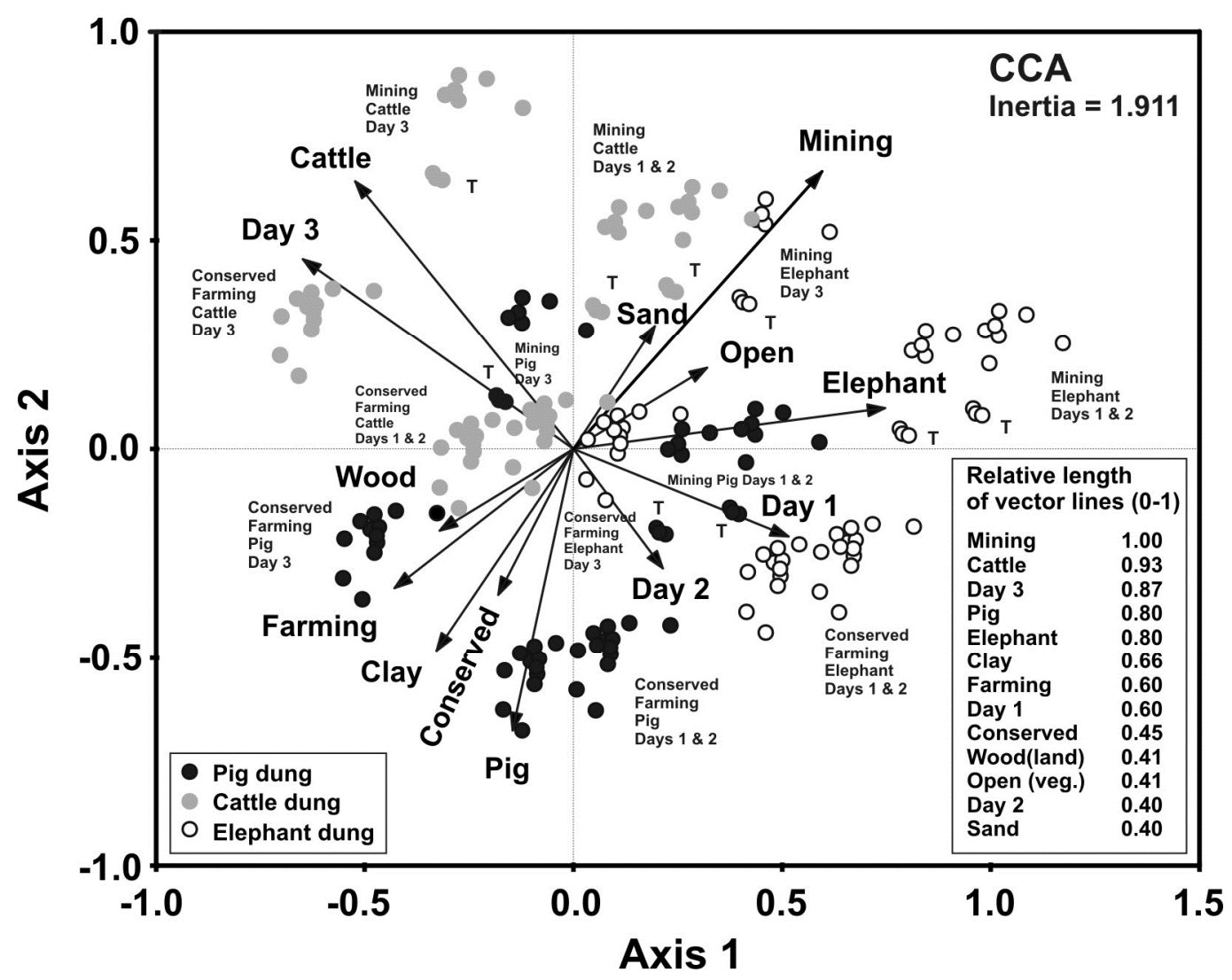

Fig. 6. Ordination plot derived from direct gradient, Canonical Correspondence Analysis (CCA) showing statistical distances between 188 dung beetle samples coded according to dung type. Vector lines represent the average trajectory of influences from dung type, land usage ( $\mathrm{T}$ = Tailings dam wall), soil texture, vegetation cover (veg.), and sampling days with different weather conditions. Lengths of vector lines represent the relative strength of environmental influences on patterns of assemblage structure.

vegetation was much more open (Table 1). In terms of angular separation, an opposing group of vectors with similar trajectories reflected the greater woody vegetation cover in farm rangeland and the greater clay fractions in both rangeland and conserved study areas (Table 1). Similar trajectories of vector lines for the warm or hot days 1 and 2 when the soil was relatively dry are opposed by those for the warm day 3 when the soil was moist (Fig. 6).

\section{Discussion}

As in other studies of disturbed areas (e.g. Botes et al. 2006; Simelane 2009; Jacobs et al. 2010; Davis et al. 2012), variation in dung beetle diversity and assemblage structure was influenced by 
a complex of overlapping and interacting environmental factors dominated, here, by dung type, land usage and weather. As there was limited variability in soil profiles and woody vegetation cover, these habitat factors were of lesser, although still appreciable, importance for shaping dung beetle assemblage structure, particularly as both were modified by some types of land usage.

Although there were clear differences between the mining complex and conserved or farmed areas, high overlap for variables within and between study areas under different land usage meant that the levels of significance were often much lower than those for dung type, weather on sampling days and their interactions. Although not studied, geographical distance is unlikely to be a strong contributor to differences since there was high similarity between assemblages in widely separated farm rangeland and conserved areas but both were dissimilar to those in the mine complex, which was adjacent to the conserved reserves.

Although ecological patterns in assemblage structure varied in emphasis between multivariate techniques and at different scales of data treatment, there were strong similarities. At coarse scale, NMDS and Factor Analysis emphasized separation of data points according to land usage or dung type. CCA emphasized separation of data points only according to dung type although the overlain vector lines emphasized the combined effects of land usage and dung type. At fine scale, CCA showed greater overlap between data points but they still emphasized separation according to dung type. However, vector lines now represented the average influence of single land usage or dung type variables. Analytical constraint of the species data by the environmental matrix resulted in clear groupings of data points according to spatial and temporal factors that were repeated for each offset trophic variable. These results suggest that dung beetle assemblages have strongly structured responses to dung type, weather and habitat variables across a range of land usage types within mopane woodland. However, it should be noted that they accounted for only a quarter of the overall variance.

The particularly strong response to dung type suggests that changes in mammal diversity and dung type availability should modify the dung beetle assemblages of farm rangeland where mammal diversity is lower than in conserved areas. In fact, dung beetle assemblage structure in farm rangeland was not substantially different to that in conserved areas despite the reduced diversity or complete absence of indigenous mammal species. This may be because all dung types were present in the farm rangeland despite the lower diversity of mammals, i.e. ruminant 
pads (buffalo or cattle) or pellets (goats), monogastric droppings (donkeys) (Fig. 2), and omnivore droppings from pigs or from baboons that were observed on the game farm (Môrelag) but, also, almost certainly forage in the communal grazing (Mashishimale). This reduced diversity of mammals, together with the high stocking rates (Table 2), presumably continue to provide an adequate supply of each type of dung to sustain similar beetle populations to those recorded in the conserved areas.

Dung beetle assemblage structure in the mining complex diverged strongly from those of conserved areas despite the occurrence of a similar diversity of large indigenous herbivores. Therefore, the influence of mining operations on dung beetle assemblages most likely reflects the modification of habitat variables, particularly changes in soil texture, and reduced availability of shade. The virtual absence of tree cover on the tailings dam wall and the coarse texture of tailings dam and rock dump soils (disturbances) were presumably responsible for the close association between vector lines for sand, open vegetation, and mining in CCA at fine scale. The bias to greater density of canopy cover in farm rangeland and finer texture of natural soils were probably responsible for the close association between vector lines for clay, woodland, farm rangeland and conservation. The results for CCA at fine scale, in particular, show the same responses to land usage on each dung type despite variation in assemblage structure with changing weather conditions that is exemplified by the opposing vector lines for days. Other studies have also found that dung beetle assemblage structure varies with physical and microclimatic factors associated with soil texture, density of woody vegetation cover and its effect on shade cover. These may result from natural variability (Cambefort 1982; Davis 1996), or, they may be induced by the impact of humans or other animals on the environment (Botes et al. 2006; Coetzee et al. 2007, Simelane 2009; Jacobs et al. 2010; Davis et al. 2012; 2013).

Although some dung beetle species did not show any consistent bias in distributions of numbers between sampling day, dung type and land usage, many showed clear trends, particularly in response to sampling day and dung type. Since weather conditions differed strongly between the three $24 \mathrm{~h}$ sampling occasions of the present study, strong temporal variation in dung beetle assemblage structure drove strong interactions between weather and environmental variables. It is likely that patterns of diversity and abundance were most strongly influenced by the high abundance of the small-bodied, night-flying, Onthophagus lamelliger Gerstaecker (41\% of total numbers). Its greater relative occurrence on Day 1 was driven by 
previous light rainfall and warm night temperatures $(67.5 \%$ of total numbers on Day 1 compared to $34.2 \%$ on Day 2 and $19.6 \%$ on Day 3 ). Furthermore, its activity was greatest in disturbed mine study areas (55-69\% of total numbers in degraded vegetation and the rock dump compared to 14$23 \%$ of total numbers in Kruger N.P., communal rangeland, and the game farm). Population dynamics of $O$. lamelliger contributed strongly to the absence of differences in abundance between sampling occasions. However, there were strong differences in biomass, which were greatest on pig dung and on day 3 after an extreme rainfall event seven days previously. This event influenced the abundance of two large-bodied species, the day flying Scarabaeus (Kheper) nigroaeneus Boheman and the night-flying Anachalcos convexus Boheman (combined 61.3\% of total biomass, and $21.5 \%$ of total biomass on Day 1, 24.8\% on Day 2, and $57.9 \%$ on Day 3). These species showed an opposite temporal trend to the small-bodied, night-flying, Onthophagus lamelliger, which had the effect of separating abundance peaks in activity by such small and large-bodied species.

Although most diurnal and crepuscular / nocturnal dung beetle species showed greater abundance on day 3 under moderate temperatures following heavy rainfall (Supplementary Table 3), some species showed different patterns. In addition to Onthophagus lamelliger, a few other small-bodied late afternoon or nocturnal species also showed greater abundance on day 1 following light rainfall a few days previously, e.g. Onthophagus aeruginosus Roth. By contrast, some mostly diurnal taxa showed greater abundance under hot sunshine on day 2, particularly small tunneling Phalops spp., some species of the ball-rolling Gymnopleurini, and kleptocoprid species in the genera Caccobius and Cleptocaccobius.

The moderating influence of rainfall on temperature is probably the reason for the much higher proportion of day fliers on day 3 compared to day 2 (Supplementary Table 3) when hot sunshine caused temperatures to climb rapidly. These high temperatures also rapidly dried the elephant dung baits. This would cause them to become unattractive to dung beetles and thus diminish the size of the day-flying sample in relation to that attracted to pig dung, which released a strong odour and probably remained attractive to dung beetles for a longer period. The very low proportion of day fliers on day 1 reflects predominantly cloudy weather since most diurnal species are active primarily in bright sunshine. These variable responses to weather conditions are the origin of differences in rank abundance between warmer drier and cooler moister weather recorded by Davis (1995). 
Despite differences in sampling protocol, a previous comparison between dung beetle assemblages in a moister part of the Kruger National Park and adjacent communal rangeland (Davis et al. 2012) yielded results that are largely consistent with those from the present study in a drier part of the Kruger National Park and nearby communal rangeland (Mashishimale). In both studies, mean species richness and abundance per trap in December were higher in the park than in communal rangeland whereas mean alpha diversity was lower. By contrast, mean biomass was higher in the communal rangeland at Phalaborwa and higher in the park in the other study (Davis et al. 2012). These differences might reflect interactions between stocking rates (park: about 10 per $\mathrm{km}^{2}$; Phalaborwa rangeland: $>130$ per $\mathrm{km}^{2}$; Welverdiend rangeland: 54 per $\mathrm{km}^{2}$ ), disturbance, and pest control procedures.

In conclusion, using the Kruger N.P. and Cleveland N.R. as benchmarks for dung beetle assemblage structure, there was limited divergence in dung beetle assemblage structure between conserved areas and farm rangeland despite differences in mammal diversity, canopy cover of woody vegetation, and manner of exploitation. This suggests that conversion of natural mopane woodland areas to game ranching or communal livestock rangeland has only a slight effect on the diversity of dung beetles in semi-arid African savanna. However, while these patterns were consistent in this study, it is unknown if such similarities would persist at greater distance from conservation areas. Ordination results suggest that mining operations were relatively much more influential on divergence in dung beetle assemblage structure despite similar mammal diversity to conserved areas, which was maintained throughout the mining complex due to its proximity to the neighbouring reserves. The differences may derive primarily from changes in soil texture and woody vegetation cover, particularly on the tailings dam wall and the rock dump, which are raised well above the original plain. Thus, even though there was relatively high proportional similarity between mine, farm rangeland and conserved assemblages, it may be said that different types of land usage in mopane woodland have been demonstrated to influence dung beetle assemblage structure in different ways and to different degrees despite the obscuring effects of dung type and weather variation. 


\section{Aknowledgements}

For extensive technical assistance, we thank staff affiliated with the Ndlovu Node of the South African Environmental Observation Network (SAEON) and the Kruger National Park: Brendan Pienaar, Patrick Ndhlovu, Rob Taylor, and Lourens Botha. We also thank the staff of the Environmental Department of the Palaborwa Mining Company for their assistance: Joseph Muharhli and Johan Macdonald. The comments of the associate editor, Melodie McGeoch, and two anonymous reviewers were most helpful in revising the manuscript. The study was jointly funded by SAEON and the Palaborwa Mining Company.

\section{References}

Botes, A., McGeoch M. A. \& van Rensburg B. J. (2006) Elephant- and human-induced changes to dung beetle (Coleoptera: Scarabaeidae) assemblages in the Maputaland Centre of Endemism. Biol. Conserv. 130, 573-83

Cambefort, Y. (1982) Les coléoptères Scarabaeidae s. str. de Lamto (Côte d'Ivoire): structure des peuplements et rôle dans l'écosystème. Ann. Soc. Entomol. Fr. 18, 433-59

Carruthers J. (2008) Wilding the farm or farming the wild? The evolution of scientific game ranching in South Africa from the 1960s to the present. T. Roy. Soc. S. Afr. 63, 160-81.

Coetzee, B. W. T., van Rensburg, B. J. \& Robertson, M. P. (2007) Invasions of grasslands by silver wattle, Acacia dealbata (Mimosaceae), alters beetle (Coleoptera) assemblage structure. Afr. Entomol. 15, 328-39

Colwell R. K. (2009) EstimateS: Statistical estimation of species richness and shared species from samples. Version 8.2. http://purl.oclc.org/estimates.

Davis A. L. V. (1995) Daily weather variation and temporal dynamics in an Afrotropical dung beetle community (Coleoptera: Scarabaeidae). Acta Oecol. 16, 641-56

Davis A. L. V. (1996) Habitat associations in a South African, summer rainfall, dung beetle community (Coleoptera: Scarabaeidae, Aphodiidae, Staphylinidae, Histeridae, Hydrophilidae). Pedobiologia 40, 260-80

Davis A. L. V. (1997) Climatic and biogeographical associations of southern African dung beetles (Coleoptera: Scarabaeidae s. str.). Afr. J. Ecol. 35, 10-38. 
Davis A. L. V., Scholtz C. H. \& Swemmer A. M. (2012) Effects of land usage on dung beetle assemblage structure: Kruger National Park versus adjacent farmland in South Africa. $J$. Insect Conserv. 16, 399-411.

Davis A. L. V., van Aarde R. J., Scholtz C. H. \& Delport J. H. (2002) Increasing representation of localized dung beetles across a chronosequence of regenerating vegetation and natural dune forest in South Africa. Global Ecol. Biogeogr. 11, 191-209

Davis A. L. V., van Aarde R. J., Scholtz C. H. \& Delport J. H. (2003) Convergence between dung beetle assemblages of a post-mining chronosequence and unmined dune forest. Restor. Ecol. 11, 29-42

Davis A. L. V., van Aarde R. J., Scholtz C. H., Guldemond R. A. R., Fourie J. \& Deschodt C. M. (2013) Is microclimate-driven turnover of dung beetle assemblage structure in regenerating coastal vegetation a precursor to re-establishment of a forest fauna? J. Insect Conserv. 17, 565-76

Dirzo R. \& Raven P. H. (2003) Global state of biodiversity and loss. Annu. Rev. Environ. Resour. 28, 137-67.

Dormont L., Jay-Robert P., Bessière J.-M., Rapior S. \& Lumaret J.-P. (2010) Innate olfactory preferences in dung beetles. J. Exp. Biol. 213, 3177-86.

Excoffier L, Laval G, Schneider S (2006) Arlequin ver. 3.1. An Integrated Software Package for Population Genetics Data Analysis. http://cmpg.unibe.ch/software/arlequin3

Estes L. \& Greyling L. (2012) Zambezian and Mopane Woodlands. WWF Wildfinder. Accessed 14.09.2012 http://worldwildlife.org/ecoregions/at0725.

Fahrig L. (2003) Effects of habitat fragmentation on biodiversity. Annu. Rev. Ecol. Evol. Syst. 34, 487-515.

Fincher G. T. (1973) Nidification and reproduction of Phanaeus spp. in three textural classes of soil (Coleoptera: Scarabaeidae). Coleopts Bull. 27, 33-7.

Halffter G. \& Favila M. E. (1993) The Scarabaeinae (Insecta: Coleoptera): an animal group for analysing, inventorying and monitoring biodiversity in tropical rainforest and modified landscapes. Biol. Int. 27, 15-21.

Hanski I. \& Cambefort Y. (1991) Competition in dung beetles. In: Dung beetle ecology (eds I. Hanski \& Y. Cambefort). pp. 305-29. Princeton University Press, Princeton. 
Happold D. C. D. (1995) The interactions between humans and mammals in Africa in relation to conservation: a review. Biodiv. Conserv. 4, 395-414.

Inouchi J. \& Shibuya T. (1986) Odour responses of the olfactory receptor cells in the dung beetles. Chem. Senses 11, 286.

Jacobs, C. T., Scholtz, C. H., Escobar, F. \& Davis, A. L. V. (2010) How might intensification of farming influence dung beetle diversity (Coleoptera: Scarabaeidae) in Maputo Special Reserve (Mozambique)? J. Insect Conserv. 14, 389-99

Jost L. (2007) Partitioning diversity into independent alpha and beta components. Ecology 88, 2427-39.

Larsen T. H. \& Forsyth A. (2005) Trap spacing and transect design for dung beetle biodiversity studies. Biotropica 37, 322-5.

Makhado R. A., Potgieter M. J. \& Wessels D. C. J. (2009) Colophospermum mopane wood utilisation in the northeast of the Limpopo Province, South Africa. Ethnobotanical Leaflets 13, 921-45.

Makhado R. A., Potgieter M.J., Wessels, D.C.J., Saidi, A. T. \& Masehela, K. K. (2012) Use of mopane woodland resources and associated woodland management challenges in rural areas of South Africa. Ethnobotany Res. Appl. 10, 369-79.

Martín-Piera F. \& Lobo J. (1996) A comparative discussion of trophic preferences in dung beetle communities. Miscellania Zool. 19, 13-31.

Mucina L. \& Rutherford M. C. eds (2006) The vegetation of South Africa, Lesotho and Swaziland. Strelitzia 19, 1-807. South African National Biodiversity Institute, Pretoria.

Musvoto C., Mapaure I., Gondo T., Ndeinoma A. \& Muja T. (2006) Reality and preferences in community mopane (Colophospermum Mopane) woodland management in Zimbabwe and Namibia. Int. J. Hum. Soc. Sci. 1, 173-7.

Nealis V. G. (1977) Habitat associations and community analysis of south Texas dung beetles (Coleoptera: Scarabaeinae). Can. J. Zool. 55, 138-47.

Newmark W.D. (2008) Isolation of African protected areas. Front. Ecol. Environ. 6, 321-8.

Nichols E., Larsen T., Spector S., Davis A. L., Escobar F., Favila M., Vulinec K. \&The Scarabaeine Research Network (2007) Global dung beetle response to tropical forest modification and fragmentation: A quantitative literature review and meta-analysis. Biol. Conserv. 137, 1-19. 
Nichols E., Gardner T. A., Peres, C.A., Spector S. \& The Scarabaeine Research Network (2009) Co-declining mammals and dung beetles: an impending ecological cascade. Oikos 118, $481-7$.

Olson D. M., Dinerstein E., Wikramanayake E. D., Burgess N. D., Powell G. V. N., Underwood E. C., d'Amico J. A., Itoua I., Strand H. E., Morrison J. C., Loucks C. J., Allnutt T. F., Ricketts T. H., Kura Y., Lamoreux J. F., Wettengel W. W., Hedao P. \& Kassem K. R. (2001) Terrestrial ecoregions of the world: a new map of life on earth. Bioscience 51, 933-8.

Rös, M., Escobar, F. \& Halffter, G. (2012) How dung beetles respond to a human modified variegated landscape in Mexican cloud forest: a study of biodiversity integrating ecological and biogeographical perspectives. Divers. Distrib. 18, 377-89.

Rutherford M. C., Powrie L. W. \& Thompson D. I. (2012) Impacts of high utilisation pressure on biodiversity components in Colophospermum mopane savanna. Afr. J. Range Forage Sci. 29, $1-11$.

Shibuya T. \& Inouchi J. (1982) Fine structure and odor responses of olfactory sensillae of the Japanese dung beetle, Copris pecuarius (Coleoptera: Scarabaeidae). Jpn. J. Appl. Entomol. Z. 26, 194-5.

Simelane T. S. (2009) Impacts of traditional land uses on biodiversity outside conservation areas; effects on dung beetle communities of Vaalbos National Park. Afr. J. Ecol. 48, 490-501.

Spector S. (2006) Scarabaeine dung beetles (Coleoptera: Scarabaeidae: Scarabaeinae): an invertebrate focal taxon for biodiversity research and conservation. Coleopts Bull. 60, $71-83$.

Stork N. E. (1988) Insect diversity: facts, fiction and speculation. Biol. J. Linn. Soc. 35, 321-37.

Ter Braak C. J. F. \& Smilauer P. (2002) CANOCO reference manual and CanoDraw for windows user's guide: software for canonical community ordination (version 4.5). Microcomputer Power, Ithaca, NY, USA.

Tshikae B. P., Davis A. L. V. \& Scholtz C. H. (2008) Trophic associations of a dung beetle assemblage (Scarabaeidae: Scarabaeinae) in a woodland savanna of Botswana. Environ. Entomol. 37, 431-41. 
Tshikae B. P., Davis A. L. V. \& Scholtz C. H. (2013a) Does an aridity and trophic resource gradient drive patterns of dung beetle food selection across the Botswana Kalahari? Ecol. Entomol. 38, 83-95.

Tshikae B. P., Davis A. L. V. \& Scholtz C. H. (2013b) Species richness - Energy relationships and dung beetle diversity across an aridity and trophic resource gradient. Acta Oecol. 49, 71-82.

Wherry R. J. (1984) Contributions to correlational analysis. Academic Press, New York. 
Supplementary Figure 1. Sample-based rarefaction of species accumulation for dung beetle assemblages recorded on three dung types in seven study areas under different land usage. The inset figure shows the average percentage accumulation of species per dung type. The inset tables show numbers of species observed (N Obs), numbers estimated (N ACE, N Boot), and proportions of species observed for each assemblage (\% ACE, \% Boot) using the Abundance-based Coverage Estimator (ACE) and the Bootstrap methods (Boot). A. Conserved study areas, B. Farm study areas, C. \& D. Study areas in the mining complex.
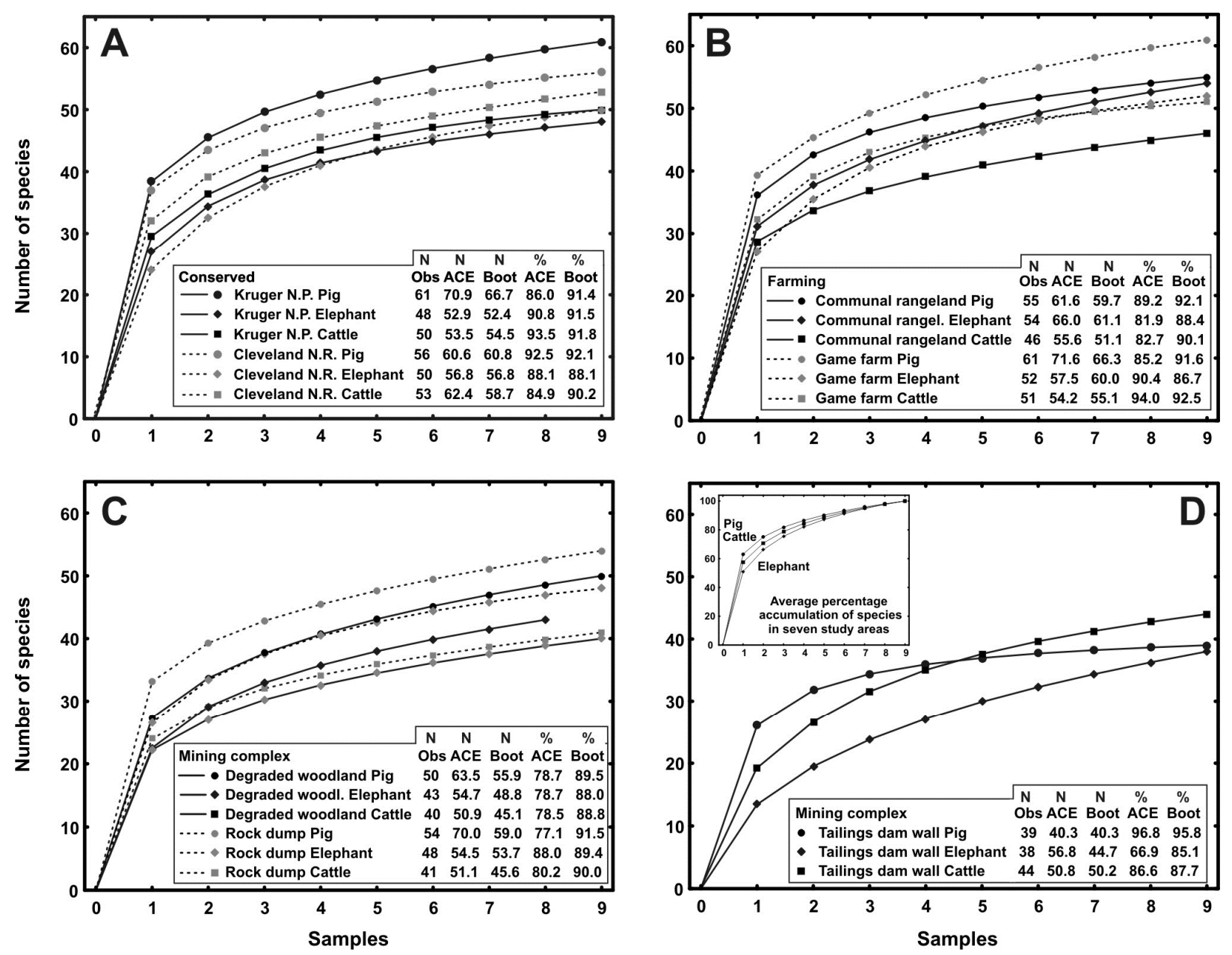
Supplementary Table 1. Descriptions of soil and woody vegetation cover at study sites near Phalaborwa.

\section{Conserved areas}

1) Kruger National Park: Open, Terminalia / Combretum-dominated, shrub / woodland on top slopes at Sites 1 and 3 with open, mopane shrub / woodland on a mid slope at Site 2, all characterized by sandy soils (average $74-84 \%$ sand, $17-27 \%$ canopy cover).

2) Cleveland Nature Reserve: Relatively more dense mopane shrubland at Sites 1 and 3 (average 29-35\% canopy cover) with Site 1 situated on a seep line with a lower sand fraction (average $65 \%$ sand) than Site 3 (77\% sand). Open, Terminalia / Combretum-dominated, shrub / woodland on sandy soils at Site 2 ( $80 \%$ sand, $23 \%$ cover).

\section{Mining complex}

3) Degraded woodland: Open shrub / woodland on a flat area adjacent to the smelting works and other mine installations with Site 1 comprising degraded mopane shrubland alongside an elephant pathway. Sites 2 and 3 comprised Acacia shrub / woodland on areas formerly cleared of woody vegetation. Sites 1 and 3 showed similar soil texture and woody vegetation cover (average $69-79 \%$ sand, $27-33 \%$ canopy cover). Site 2 was in area previously covered by a spillage of tailings sediments with a high sand fraction $(91 \%$ sand). There is no vegetation data for Site 2 as it was converted into a parking area before measurements could be made.

4) Tailings dam wall: Early succession patchy grassland (average herbaceous cover $76 \%$ compared to 83 $93 \%$ in other study areas) with scattered shrubs (2-3\% canopy cover) on the third level of the terraced dam wall 10-15 m above the adjoining Cleveland Nature Reserve. The dam wall overlies the former plain and is constructed from copper tailings overlain by crushed vermiculite. The sand fraction is very high (95-98\%) and exceeds that of the average shown by undisturbed granite-derived soils of the undisturbed areas (65-84\% sand).

5) Rock dump (Vermiculite dump): Later succession (>30 year old) open Acacia shrub / woodland on the top of an artificial hill about $40 \mathrm{~m}$ above the underlying former plain. The vegetation was established on vermiculite rock fragments with a very high sand fraction (average 90-95\% sand, 24-26\% canopy cover).

\section{Farm rangeland}

6) Game Farm (Môrelag): Open to fairly dense mopane-dominated woodland with Site 1 in bottomland and Sites 2 and 3 on top lands. There was more sand and more open woodland at Site 2 (average 87\% sand, $28 \%$ canopy cover) than at the other two sites ( $74-77 \%$ sand, $45-47 \%$ cover). The woodland was taller and much less disturbed than at Sites 2 and 3 in Mashishimale.

7) Communal rangeland (Mashishimale): A mosaic of small enclosures cleared of woody vegetation, grassland patches, and open shrubland, mostly disturbed. Sites 1 and 2 were on top lands and comprised, respectively, dense mopane-dominated shrubland next to the Môrelag fence and Acacia dominated shrubland at $1 \mathrm{~km}$ distance from the fence (average $82-84 \%$ sand, $40-44 \%$ canopy cover). Site 3 comprised less sand and more open shrub / grassland (74\% sand, $28 \%$ cover) along a seep line at $2 \mathrm{~km}$ distance from the fence. 
Supplementary Table 2. Expressions used to partition gamma species richness and diversity into independent alpha and beta values (see Jost 2007)

To partition gamma species richness $\left({ }^{0} \mathrm{D}_{\gamma}\right)$ into alpha $\left({ }^{0} \mathrm{D}_{\alpha}\right)$ and beta diversity $\left({ }^{0} \mathrm{D}_{\beta}\right)$, the following expressions were used:

${ }^{0} \mathrm{D}_{\gamma}=\mathrm{S}$

${ }^{0} \mathrm{D}_{\alpha}=(1 / \mathrm{N})\left(\mathrm{S}_{1}+\mathrm{S}_{2}+\ldots+\mathrm{S}_{\mathrm{j}}\right)$

${ }^{0} \mathrm{D}_{\beta}={ }^{0} \mathrm{D}_{\gamma} /{ }^{0} \mathrm{D}_{\alpha}$

where $\mathrm{S}$ is the total number of species in all sampling units, $\mathrm{S}_{\mathrm{j}}$ is the number of species per sampling unit, and $\mathrm{N}$ is the total number of sampling units. In the present study, the sampling units for analysis of spatial patterns were the seven study areas and those for the analysis of trophic patterns were the three bait types.

To partition gamma exponential Shannon-Wiener diversity $\left({ }^{1} \mathrm{D}_{\gamma}\right)$ into alpha $\left({ }^{1} \mathrm{D}_{\alpha}\right)$ and beta $\left({ }^{1} \mathrm{D}_{\beta}\right)$ diversity, the following expressions were used:

${ }^{1} \mathrm{D}_{\gamma}=\exp \left[-\sum_{\mathrm{n}=1}^{\mathrm{s}}\left(p_{\mathrm{i}} \ln p_{\mathrm{i}}\right)\right]$

${ }^{1} \mathrm{D}_{\alpha}=\exp \left[-w_{1} \sum_{\mathrm{n}=1}^{\mathrm{s}}\left(p_{\mathrm{i} 1} \ln p_{\mathrm{i} 1}\right)+-w_{2} \sum_{\mathrm{n}=1}^{\mathrm{s}}\left(p_{\mathrm{i} 2} \ln p_{\mathrm{i} 2}\right)+\ldots.\right]$

$w_{\mathrm{j}}=$ ind $_{\mathrm{j}} /$ ind $_{\mathrm{tot}}$

${ }^{1} \mathrm{D}_{\beta}={ }^{1} \mathrm{D}_{\gamma} /{ }^{1} \mathrm{D}_{\alpha}$

where $p$ is the decimal proportion of individuals of each species in all sampling units $\left({ }^{1} \mathrm{D}_{\gamma}\right)$, or each sampling unit $\left({ }^{1} \mathrm{D}_{\alpha}\right)$, and $w$ is the statistical weight contributed by each sampling unit to the total diversity. The statistical weight $(w)$ is calculated from the number of individuals in community $j\left(\right.$ ind $_{\mathrm{j}}$ ) divided by the total number of individuals (ind $\mathrm{tot}_{\mathrm{to}}$.

Extra reference for Supplementary Table 3.

Doube, B. M. (1991) Appendix Table B8. In: Dung beetle ecology (eds I. Hanski \& Y. Cambefort). pp. 382-87. Princeton University Press, Princeton. 
Supplementary Table 3. Total abundances of 107 dung beetle species recorded on three dung types under different weather conditions in conserved, mined and farm rangeland areas at Phalaborwa in December 2011 and January 2012 with diel flight pattern and average dry mass of individuals

Abundance in study areas*

Abundance on dung types** Abundance per sample***

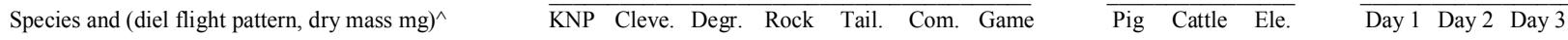

Anachalcos convexus Boheman (N, 669.2) $\quad \begin{array}{lllllll}111 & 153 & 59 & 71 & 15 & 114 & 163\end{array}$

Odontoloma sp. (D, $1.4^{\mathrm{e}}$ )

Scarabaeus (Kheper) cupreus (Castelnau) (N, 800.0 ${ }^{\mathrm{e}}$ )

Scarabaeus (Kheper) lamarcki Macleay (D, 1403.8)

$\begin{array}{rrrrrrr}1 & 0 & 2 & 8 & 0 & 0 & 0\end{array}$

$\begin{array}{rrrrrrrr}0 & 1 & 0 & 0 & 0 & 0 & 0\end{array}$

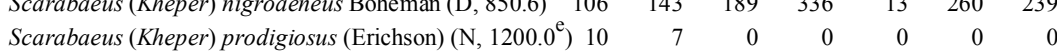

Scarabaeus (Kheper) subaeneus Harold (D, 1057.9)

Scarabaeus (Scarabaeolus) bohemani Harold (D, 52.0)

Scarabaeus (Scarabaeolus) clanceyi Ferreira (D, 25.0 ${ }^{\mathrm{e}}$ ) 78

Scarabaeus (Scarabaeus) deludens zur Strassen (N, 281.0 $0^{\mathrm{e}} \quad 0$

Scarabaeus (Scarabaeus) galenus Westwood (D, 431.2 ${ }^{\mathrm{e}}$ )

Scarabaeus (Scarabaeus) goryi (Castelnau) (N, 1198.6)

Scarabaeus (Scarabaeus) interstitialis (Boheman) (D, 80.0 $0^{\mathrm{e}}$

Allogymnopleurus thalassinus (Klug) (D, 76.4)

Garreta nitens (Olivier) (D, 207.8)

Gymnopleurus aenescens Wiedemann (D, 30.0 $\mathrm{e}^{\mathrm{e}}$ )

Gymnopleurus humeralis Klug (D, 60.0 ${ }^{\mathrm{e}}$ )

Gymnopleurus virens Erichson (D, 49.6)

Neosisyphus calcaratus (Klug) (D, 9.9)

Neosisyphus fortuitus Péringuey (D, 22.0 ${ }^{\mathrm{e}}$ )

Neosisyphus rubrus Paschalidis (D, 11.8)

Neosisyphus infuscatus (Klug) (D, 12.4)

Sisyphus goryi Harold (D, 9.8)

Sisyphus sordidus Boheman (D, 19.0 ${ }^{\mathrm{e}}$ )

Heliocopris andersoni Bates (N, 1606.1)

Heliocopris neptunus Boheman (N, 1046.3)

Pedaria sp. 1 sensu Doube (1991) (N, 9.3)

Pedaria cylindrica Boheman (N, 12.0 ${ }^{\mathrm{e}}$ )

Sarophorus costatus Fahraeus (D, 21.5)

Copris amyntor Klug (N, 102.5)

Copris denticulatus Nguyen Phung (N, 269.0 ${ }^{\mathrm{e}}$ )

Copris elphenor Klug (N, 352.5)

Copris evanidus Klug (N, 52.6 ${ }^{\mathrm{e}}$ )

Copris mesacanthus Harold (N, 107.0 ${ }^{\mathrm{e}}$ )

Catharsius pandion Harold (N, 404.6)

Catharsius philus Kolbe (N, 187.6)

Catharsius platycerus $\mathrm{Klug}\left(\mathrm{N}, 900.0^{\mathrm{e}}\right.$ )

Metacatharsius opacus (Waterhouse) (N, 72.8)

Metacatharsius troglodytes (Boheman) (N, 43.5)

Cheironitis indicus van Lansberge (D, 50.0 ${ }^{\mathrm{e}}$ )

Heteronitis castelnaui (Harold) (D, 950.0 $\left.{ }^{\mathrm{e}}\right)$

Onitis alexis $\mathrm{Klug}(\mathrm{N}, 102.6)$

Onitis fulgidus Klug (N, 121.9)

Onitis obenbergeri Balthasar $\left(\mathrm{N}, 95.0^{\mathrm{e}}\right)$

Onitis pseudosetosus Ferreira (N, 122.0 $\left.{ }^{\mathrm{e}}\right)$

Onitis inversidens van Lansberge (N, 168.6)

Onitis uncinatus Klug (N, 141.8)

Onitis westermanni van Lansberge (N, 101.0 $\left.{ }^{\mathrm{e}}\right)$

Caccobius ferrugineus Fahraeus (N, 5.3)

Caccobius nigritulus Klug (D, 3.3)

Caccobius sp. 2 sensu Davis et al. (2002) (?, 1.5)

Caccobius sp. 4 sensu Doube (1991) (?, 6.0 ${ }^{\mathrm{e}}$ )

Cleptocaccobius viridicollis (Fahraeus) (D, 0.9)

Digitonthophagus gazella (Fabricius) (N, 35.4)

Euonthophagus carbonarius Klug (N, 18.0)

Hyalonthophagus alcyonides (d'Orbigny) (D, 22.2)

Milichus apicalis (Fahraeus) (N, 12.8)

\begin{tabular}{|c|c|c|c|c|c|c|}
\hline 158 & 174 & 18 & 21 & 44 & 930 & 237 \\
\hline 17 & 99 & 72 & 57 & 40 & 13 & 109 \\
\hline 71 & 11 & 0 & 1 & 2 & 120 & 49 \\
\hline 51 & 112 & 1 & 3 & 12 & 4 & 1 \\
\hline 4 & 46 & 48 & 121 & 16 & 0 & 28 \\
\hline 106 & 55 & 6 & 42 & 10 & 63 & 528 \\
\hline 0 & 0 & 0 & 0 & 0 & 0 & 1 \\
\hline 2 & 6 & 76 & 103 & 19 & 140 & 124 \\
\hline 3 & 8 & 13 & 6 & 11 & 15 & 22 \\
\hline 1427 & 1497 & 243 & 779 & 198 & 581 & 1670 \\
\hline 0 & 0 & 0 & 0 & 0 & 0 & 3 \\
\hline 0 & 0 & 2 & 1 & 1 & 0 & 0 \\
\hline 0 & 0 & 0 & 0 & 0 & 0 & 2 \\
\hline 27 & 11 & 3 & 6 & 0 & 28 & 10 \\
\hline 3 & 0 & 0 & 1 & 0 & 3 & 4 \\
\hline 3 & 11 & 0 & 2 & 0 & 7 & 66 \\
\hline 4 & 2 & 14 & 11 & 2 & 0 & 0 \\
\hline 0 & 0 & 0 & 1 & 0 & 0 & 0 \\
\hline 33 & 9 & 2 & 2 & 0 & 31 & 10 \\
\hline 0 & 0 & 2 & 6 & 0 & 0 & 4 \\
\hline 0 & 1 & 0 & 0 & 0 & 0 & 1 \\
\hline 0 & 0 & 0 & 0 & 0 & 0 & 1 \\
\hline 8 & 15 & 31 & 15 & 0 & 18 & 9 \\
\hline 1 & 0 & 0 & 0 & 0 & 0 & 0 \\
\hline 26 & 16 & 0 & 0 & 1 & 59 & 20 \\
\hline 23 & 34 & 1 & 0 & 0 & 56 & 2 \\
\hline 1 & 1 & 0 & 0 & 0 & 0 & 0 \\
\hline 0 & 0 & 1 & 0 & 0 & 1 & 0 \\
\hline 4 & 0 & 1 & 1 & 0 & 0 & 0 \\
\hline 0 & 0 & 1 & 3 & 1 & 0 & 15 \\
\hline 29 & 32 & 13 & 26 & 4 & 58 & 83 \\
\hline 1 & 0 & 0 & 0 & 0 & 0 & 0 \\
\hline 0 & 0 & 1 & 2 & 0 & 1 & 0 \\
\hline 16 & 6 & 9 & 7 & 2 & 9 & 10 \\
\hline 0 & 1 & 1 & 0 & 0 & 0 & 0 \\
\hline 248 & 85 & 15 & 30 & 26 & 305 & 34 \\
\hline 657 & 44 & 67 & 43 & 17 & 11 & 29 \\
\hline 435 & 131 & 50 & 208 & 13 & 31 & 134 \\
\hline 0 & 0 & 0 & 1 & 0 & 0 & 0 \\
\hline 121 & 249 & 55 & 124 & 64 & 242 & 312 \\
\hline 78 & 51 & 126 & 29 & 82 & 30 & 6 \\
\hline 1911 & 1031 & 1648 & 836 & 491 & 368 & 967 \\
\hline 0 & 0 & 0 & 2 & 0 & 0 & 0 \\
\hline 7 & 1 & 3 & 0 & 17 & 7 & 9 \\
\hline
\end{tabular}

\begin{tabular}{|c|c|c|c|c|c|}
\hline 542 & 36 & 108 & 185 & 202 & 302 \\
\hline 8 & 2 & 1 & 7 & 2 & 2 \\
\hline 9 & 9 & 0 & 2 & 1 & 15 \\
\hline 1 & 0 & 0 & 0 & 1 & 0 \\
\hline 736 & 406 & 144 & 110 & 190 & 981 \\
\hline 15 & 1 & 1 & 0 & 3 & 14 \\
\hline 60 & 4 & 3 & 3 & 6 & 58 \\
\hline 41 & 6 & 4 & 18 & 9 & 24 \\
\hline 110 & 6 & 0 & 7 & 88 & 21 \\
\hline 0 & 0 & 1 & 0 & 0 & 1 \\
\hline 4 & 21 & 1 & 1 & 1 & 24 \\
\hline 5 & 0 & 0 & 0 & 3 & 2 \\
\hline 4 & 0 & 0 & 0 & 0 & 4 \\
\hline 1046 & 358 & 178 & 129 & 944 & 380 \\
\hline 332 & 50 & 25 & 119 & 199 & 88 \\
\hline 179 & 48 & 27 & 8 & 49 & 195 \\
\hline 162 & 21 & 1 & 27 & 151 & 6 \\
\hline 190 & 26 & 47 & 26 & 47 & 190 \\
\hline 230 & 450 & 130 & 21 & 225 & 554 \\
\hline 1 & 0 & 0 & 0 & 0 & 1 \\
\hline 93 & 287 & 90 & 3 & 104 & 322 \\
\hline 15 & 49 & 14 & 2 & 28 & 42 \\
\hline 3041 & 2770 & 584 & 554 & 1904 & 3839 \\
\hline 1 & 1 & 1 & 0 & 0 & 3 \\
\hline 1 & 0 & 3 & 0 & 3 & 1 \\
\hline 2 & 0 & 0 & 0 & 0 & 2 \\
\hline 22 & 26 & 37 & 5 & 3 & 77 \\
\hline 2 & 2 & 7 & 2 & 0 & 9 \\
\hline 62 & 11 & 16 & 2 & 12 & 75 \\
\hline 4 & 3 & 26 & 16 & 11 & 6 \\
\hline 0 & 1 & 0 & 0 & 0 & 1 \\
\hline 1 & 72 & 14 & 4 & 3 & 78 \\
\hline 0 & 1 & 11 & 5 & 4 & 3 \\
\hline 0 & 1 & 1 & 0 & 0 & 2 \\
\hline 0 & 0 & 1 & 0 & 1 & 0 \\
\hline 32 & 57 & 7 & 4 & 3 & 88 \\
\hline 0 & 0 & 1 & 0 & 0 & 1 \\
\hline 65 & 22 & 35 & 29 & 7 & 86 \\
\hline 51 & 49 & 16 & 23 & 25 & 66 \\
\hline 2 & 0 & 0 & 0 & 2 & 0 \\
\hline 0 & 0 & 2 & 1 & 0 & 1 \\
\hline 1 & 4 & 1 & 1 & 3 & 2 \\
\hline 12 & 2 & 6 & 7 & 8 & 5 \\
\hline 35 & 14 & 196 & 96 & 24 & 128 \\
\hline 1 & 0 & 0 & 0 & 1 & 0 \\
\hline 1 & 0 & 3 & 2 & 1 & 1 \\
\hline 2 & 30 & 27 & 19 & 23 & 17 \\
\hline 1 & 1 & 0 & 0 & 1 & 1 \\
\hline 559 & 74 & 110 & 256 & 266 & 210 \\
\hline 652 & 41 & 175 & 89 & 653 & 126 \\
\hline 673 & 217 & 112 & 184 & 579 & 239 \\
\hline 1 & 0 & 0 & 1 & 0 & 0 \\
\hline 758 & 328 & 81 & 288 & 559 & 263 \\
\hline 182 & 144 & 76 & 89 & 80 & 232 \\
\hline 3930 & 625 & 2697 & 2319 & 3954 & 1028 \\
\hline 2 & 0 & 0 & 1 & 0 & 1 \\
\hline 2 & 2 & 40 & 8 & 5 & 31 \\
\hline
\end{tabular}


Supplementary Table 3 cont.

\begin{tabular}{|c|c|c|c|c|c|c|c|c|c|c|c|c|c|}
\hline \multirow[b]{2}{*}{ Species and (diel flight pattern, body dry mass $\mathrm{mg})^{\wedge}$} & \multicolumn{7}{|c|}{ Abundance in study areas* } & \multicolumn{6}{|c|}{ Abundance on dung types** Abundance per sample*** } \\
\hline & KNP & Cleve. & Degr. & Rock & Tail. & Com. & Game & Pig & Cattle & Ele. & Day 1 & Day 2 & Day 3 \\
\hline Onthophagus aeruginosus Roth (D, 9.2) & 14 & 9 & 139 & 175 & 27 & 2 & 75 & 285 & 72 & 84 & 171 & 92 & 178 \\
\hline Onthophagus albipodex d'Orbigny $(?, 15.4)$ & 0 & 0 & 0 & 0 & 0 & 0 & 1 & 1 & 0 & 0 & 0 & 1 & 0 \\
\hline Onthophagus apiciosus d'Orbigny (N, 12.5) & 0 & 1 & 1 & 1 & 0 & 1 & 4 & 7 & 0 & 1 & 4 & 2 & 2 \\
\hline Onthophagus convexus d'Orbigny (D, $\left.1.01^{\mathrm{e}}\right)$ & 60 & 38 & 1 & 20 & 0 & 25 & 11 & 35 & 105 & 15 & 27 & 73 & 50 \\
\hline Onthophagus corniculiger d'Orbigny $\left(\mathrm{N}, 12.0^{\mathrm{e}}\right)$ & 0 & 0 & 0 & 0 & 0 & 1 & 0 & 0 & 0 & 1 & 0 & 0 & 1 \\
\hline Onthophagus depressus Harold (N, $24.9^{\mathrm{e}}$ ) & 0 & 0 & 0 & 0 & 0 & 0 & 3 & 3 & 0 & 0 & 0 & 3 & 0 \\
\hline O. fimetarius Roth / O. leroyi d'Orbigny (N, 9.5) & 55 & 100 & 450 & 565 & 69 & 76 & 1345 & 1393 & 1007 & 260 & 603 & 1392 & 664 \\
\hline Onthophagus flavolimbatus Klug (D, 2.9) & 305 & 300 & 62 & 105 & 13 & 817 & 811 & 1001 & 1061 & 351 & 55 & 794 & 1391 \\
\hline Onthophagus lamelliger Gerstaecker (N, 4.2) & 2670 & 7572 & 9238 & 8290 & 1191 & 1520 & 1829 & 21850 & 4125 & 6335 & 18612 & 8544 & 5146 \\
\hline Onthophagus obtusicornis Fahraeus (D, 15.2) & 7 & 9 & 6 & 6 & 49 & 6 & 70 & 119 & 20 & 14 & 36 & 25 & 92 \\
\hline Onthophagus pallidipennis Fahraeus $(\mathrm{D}, 6.0)$ & 56 & 48 & 9 & 52 & 6 & 134 & 76 & 173 & 186 & 22 & 19 & 66 & 295 \\
\hline Onthophagus pauxillus d'Orbigny (D, $1.2^{\mathrm{e}}$ ) & 67 & 15 & 7 & 10 & 4 & 38 & 259 & 163 & 215 & 22 & 64 & 34 & 302 \\
\hline Onthophagus sp. near pullus (horned) (D, $1.2^{\mathrm{e}}$ ) & 0 & 0 & 1 & 1 & 0 & 1 & 68 & 66 & 5 & 0 & 10 & 0 & 61 \\
\hline Onthophagus rasipennis d'Orbigny (D, 3.4) & 613 & 1063 & 350 & 1798 & 637 & 1195 & 1708 & 4025 & 2488 & 851 & 1157 & 1374 & 4763 \\
\hline Onthophagus ?rugulipennis Fairmaire $\left(?, 3.2^{\mathrm{e}}\right)$ & 1 & 8 & 0 & 0 & 0 & 0 & 0 & 3 & 6 & 0 & 9 & 0 & 0 \\
\hline Onthophagus signatus Fahraeus (D, 6.4) & 242 & 161 & 5 & 16 & 15 & 10 & 6 & 238 & 160 & 57 & 148 & 103 & 204 \\
\hline Onthophagus stellio Erichson (N, 2.8) & 1002 & 348 & 14 & 20 & 19 & 692 & 114 & 1520 & 124 & 565 & 741 & 414 & 1053 \\
\hline Onthophagus suffusus Klug (N, 4.3) & 368 & 151 & 19 & 19 & 15 & 209 & 70 & 741 & 5 & 105 & 437 & 210 & 206 \\
\hline Onthophagus sp. near suffusus $\left(?, 2.8^{\mathrm{e}}\right)$ & 0 & 2 & 0 & 0 & 0 & 0 & 0 & 2 & 0 & 0 & 2 & 0 & 0 \\
\hline Onthophagus sp. near sugillatus sp. $3\left(\mathrm{D}, 3.2^{\mathrm{e}}\right)$ & 21 & 8 & 40 & 248 & 9 & 28 & 2 & 198 & 80 & 78 & 65 & 172 & 126 \\
\hline Onthophagus sugillatus $\mathrm{Klug}\left(\mathrm{D}, 2.0^{\mathrm{e}}\right)$ & 25 & 7 & 1 & 0 & 0 & 45 & 713 & 472 & 108 & 211 & 587 & 137 & 67 \\
\hline Onthophagus verticalis Fahraeus $(\mathrm{N}, 7.8)$ & 0 & 1 & 0 & 0 & 0 & 1 & 1 & 1 & 0 & 2 & 0 & 0 & 3 \\
\hline Onthophagus vinctus Erichson (N, 7.6) & 0 & 0 & 15 & 1 & 14 & 0 & 4 & 19 & 1 & 14 & 12 & 8 & 14 \\
\hline Onthophagus virescens Harold $\left(\mathrm{D}, 6.0^{\mathrm{e}}\right.$ ) & 5 & 0 & 1 & 0 & 0 & 0 & 0 & 5 & 1 & 0 & 1 & 2 & 3 \\
\hline Onthophagus sp. a (?, ?) & 0 & 0 & 1 & 0 & 0 & 0 & 0 & 0 & 1 & 0 & 0 & 0 & 1 \\
\hline Onthophagus sp. b (?, ?) & 1 & 0 & 0 & 0 & 0 & 0 & 0 & 1 & 0 & 0 & 0 & 1 & 0 \\
\hline Onthophagus sp. c (?,?) & 0 & 1 & 0 & 0 & 0 & 0 & 0 & 1 & 0 & 0 & 0 & 1 & 0 \\
\hline Onthophagus sp. d (?, ?) & 0 & 0 & 0 & 0 & 0 & 0 & 1 & 1 & 0 & 0 & 1 & 0 & 0 \\
\hline Onthophagus sp. e (?, ?) & 1 & 0 & 0 & 0 & 0 & 0 & 0 & 1 & 0 & 0 & 1 & 0 & 0 \\
\hline Phalops ardea (Klug) (D, 42.5) & 68 & 113 & 4 & 12 & 33 & 16 & 46 & 234 & 41 & 17 & 13 & 243 & 35 \\
\hline Phalops boschas Klug (D, 26.1) & 17 & 44 & 7 & 37 & 15 & 30 & 51 & 173 & 19 & 9 & 9 & 176 & 16 \\
\hline Phalops dregei Harold (D, 27.8) & 12 & 22 & 1 & 6 & 16 & 117 & 36 & 140 & 43 & 27 & 20 & 141 & 26 \\
\hline Phalops flavocinctus Klug (D, 33.1) & 2 & 29 & 9 & 13 & 20 & 0 & 0 & 60 & 6 & 7 & 2 & 58 & 13 \\
\hline Phalops smaragdinus Harold (D, 49.8) & 0 & 0 & 0 & 0 & 0 & 4 & 4 & 8 & 0 & 0 & 0 & 4 & 4 \\
\hline Proagoderus bicallosus (Klug) (D, ) & 1 & 0 & 0 & 0 & 0 & 0 & 0 & 1 & 0 & 0 & 0 & 0 & 1 \\
\hline Proagoderus loricatus (Klug) (D, 53.5) & 5 & 3 & 4 & 13 & 3 & 2 & 5 & 32 & 2 & 1 & 2 & 28 & 5 \\
\hline Proagoderus rangifer (Klug) (D, 38.7) & 0 & 0 & 0 & 0 & 0 & 1 & 45 & 41 & 2 & 3 & 2 & 11 & 33 \\
\hline Drepanocerus kirbyi Kirby (D, 1.7) & 22 & 25 & 69 & 106 & 7 & 27 & 55 & 17 & 192 & 102 & 14 & 69 & 226 \\
\hline Drepanocerus patrizii (Boucomont) (D, $5.3^{\mathrm{e}}$ ) & 1 & 0 & 0 & 0 & 1 & 4 & 0 & 0 & 3 & 3 & 0 & 1 & 5 \\
\hline Eodrepanus fastiditus Péringuey (D, $2.8^{\mathrm{e}}$ ) & 2 & 3 & 3 & 4 & 2 & 1 & 0 & 0 & 2 & 13 & 0 & 13 & 2 \\
\hline Ixodina sp. near freyi (D, $\left.1.0^{\mathrm{e}}\right)$ & 1 & 7 & 7 & 11 & 3 & 1 & 0 & 2 & 1 & 27 & 2 & 28 & 0 \\
\hline Latodrepanus laticollis (Fahraeus) $\left(\mathrm{D}, 2.8^{\mathrm{e}}\right.$ ) & 50 & 20 & 1 & 6 & 3 & 261 & 77 & 9 & 240 & 169 & 2 & 68 & 320 \\
\hline Euoniticellus intermedius (Reiche) (D, 8.6) & 115 & 99 & 157 & 384 & 33 & 275 & 124 & 23 & 1049 & 115 & 30 & 157 & 951 \\
\hline Euoniticellus sp. (D, $\left.2.8^{\mathrm{e}}\right)$ & 0 & 0 & 0 & 5 & 1 & 0 & 0 & 1 & 0 & 5 & 2 & 4 & 0 \\
\hline Liatongus militaris (Castelnau) (D, 27.1 ${ }^{\mathrm{e}}$ ) & 0 & 1 & 9 & 11 & 4 & 0 & 1 & 0 & 4 & 22 & 4 & 20 & 2 \\
\hline Oniticellus egregius $\mathrm{Klug}\left(\mathrm{D}, 40.0^{\mathrm{e}}\right)$ & 0 & 0 & 2 & 0 & 0 & 0 & 0 & 0 & 0 & 2 & 0 & 2 & 0 \\
\hline Oniticellus formosus Chevrolat (D, $13.3^{\mathrm{e}}$ ) & 5 & 8 & 1 & 6 & 12 & 0 & 2 & 0 & 2 & 32 & 0 & 29 & 6 \\
\hline Oniticellus planatus Castelnau (D, $16.0^{\mathrm{e}}$ ) & 0 & 0 & 0 & 4 & 1 & 0 & 0 & 0 & 0 & 5 & 0 & 5 & 0 \\
\hline Tiniocellus spinipes $\operatorname{Roth}\left(\mathrm{D}, 8.0^{\mathrm{e}}\right)$ & 1 & 0 & 0 & 0 & 1 & 0 & 0 & 0 & 0 & 2 & 2 & 0 & 0 \\
\hline Tiniocellus eurypygus Branco (D, 10.5) & 16 & 46 & 20 & 46 & 16 & 27 & 31 & 55 & 30 & 117 & 23 & 84 & 96 \\
\hline Total & 11648 & 14638 & 13435 & 14903 & 3348 & 9136 & 12574 & 47001 & 17684 & 14727 & 27562 & 249772 & 26211 \\
\hline Percentage abundance of day fliers & & & & & & & & & & & 14.1 & $1 \quad 36.8$ & $8 \quad 62.6$ \\
\hline Total biomass ( $\mathrm{g}$ ) & & & & & & & & & & & 436 & 651 & 1442 \\
\hline
\end{tabular}

*Land usage: Conservation - KNP: Kruger National Park, Cleve.: Cleveland Nature Reserve; Mine complex - Degr.: Degraded woodland, Rock: Rock dump, Tail.: Tailings dam wall; Farm rangeland - Game: Game farm (Môrelag), Com.: Communal rangeland (Mashishimale). **Ele.: Elephant dung.

***Day 1 (5-6 Dec.): Mild to warm and cloudy with late afternoon sunshine following light rain two days previously (6.6 mm); Day 2 (6-7 Dec.): Sunny, hot and dry, $12-$ 14 days since previous substantial rainfall $(35.8 \mathrm{~mm})$; Day 3 (25-26 Jan.): Sunny and warm, 7-8 days after very substantial rainfall $(174.4 \mathrm{~mm})$.

^(D): Diurnal flight activity; (N): Crepuscular or nocturnal flight activity; (?): Flight activity unknown; Average dry mass per individual recorded in the KNP at the South African Wildlife College (24.541 S 31.335 E), or elsewhere ${ }^{\mathrm{e}}$. 